\section{Pacific Northwest}

National Laboratory

Operated by Battelle for the

U.S. Department of Energy

\title{
Possible Incorporation of Neptunium in Uranyl (VI) Alteration Phases
}
E. C. Buck
M. Douglas
B. K. McNamara
B. D. Hanson

November 2003

Prepared for the U.S. Department of Energy under Contract DE-AC06-76RL01830 


\title{
DISCLAIMER
}

This report was prepared as an account of work sponsored by an agency of the United States Government. Neither the United States Government nor any agency thereof, nor Battelle Memorial Institute, nor any of their employees, makes any warranty, express or implied, or assumes any legal liability or responsibility for the accuracy, completeness, or usefulness of any information, apparatus, product, or process disclosed, or represents that its use would not infringe privately owned rights. Reference herein to any specific commercial product, process, or service by trade name, trademark, manufacturer, or otherwise does not necessarily constitute or imply its endorsement, recommendation, or favoring by the United States Government or any agency thereof, or Battelle Memorial Institute. The views and opinions of authors expressed herein do not necessarily state or reflect those of the United States Government or any agency thereof.

\author{
PACIFIC NORTHWEST NATIONAL LABORATORY \\ operated by \\ BATTELLE \\ for the \\ UNITED STATES DEPARTMENT OF ENERGY \\ under Contract DE-AC06-76RL01830
}

This document was printed on recycled paper. 


\title{
Possible Incorporation of Neptunium in Uranyl (VI) Alteration Phases
}

\author{
E. C. Buck \\ B. K. McNamara \\ M. Douglas \\ B. D. Hanson
}

November 2003

Prepared for the U.S. Department of Energy

under Contract DE-AC06-76RL01830

Pacific Northwest National Laboratory

Richland, Washington, 99352 


\section{Summary}

This report examines the ability of Electron Energy-Loss Spectroscopy (EELS) on the Transmission Electron Microscope (TEM) to detect low levels of neptunium $(\mathrm{Np})$ in a uranium matrix and in the possible presence of rare earth and transuranic elements. Verification of this technique is necessary to support the case for using uranium (VI) secondary minerals from corroded spent fuel as the solubilitycontrolling phases for $\mathrm{Np}$ in the Yucca Mountain performance assessment model. In this report, the use of EELS to detect $\mathrm{Np}$ at low levels in uranium phases is examined through analysis of data from spent fuel tests and synthesis tests. Because TEM-EELS is a high spatial resolution technique it provides one of the most suitable methods for probing the nature of sub-micron multiphase solids, such as those formed during the corrosion of spent fuel.

The detection of $\mathrm{Np}$ in a matrix of uranium (U) can be impeded by the occurrence of a plural scattering event from $\mathrm{U}\left(\mathrm{U}-\mathrm{M}_{5}+\mathrm{U}-\mathrm{O}_{4,5}\right)$ that results in severe overlap on the Np-M $\mathrm{M}_{5}$ edge at $3665 \mathrm{eV}$. By examining the energy gap between the $\mathrm{Np}-\mathrm{M}_{5}$ and $\mathrm{Np}-\mathrm{M}_{4}$ edges $(184 \mathrm{eV})$, a method for observing $\mathrm{Np}$ independently of the plural scattering event has been established, confirming earlier results suggesting coprecipitation of $\mathrm{Np}$ and $\mathrm{U}$ in some solids. Clear evidence of $\mathrm{Np}$ incorporation into studtite and uranophane has been found in laboratory tests using EELS. Preliminary results from the examination of a spent fuel solid with radiochemical methods suggests limited uptake of $\mathrm{Np}$ into the uranyl (VI) alteration phase.

The objective of this work was to evaluate the application of EELS on the Transmission Electron Microscope (TEM) for detecting $\mathrm{Np}$ in a $\mathrm{U}$ matrix. A series of limited tests were run to determine possible evidence of $\mathrm{Np}$ incorporation into uranyl (VI) solids. EELS data on $\mathrm{Np}$ solids at ANL were reexamined. Synthesized Np-doped uranyl phases were examined with X-ray diffraction (XRD), Raman, Optical Microscopy, and TEM-EELS. Microstructural and radiochemical analysis of alteration phases

from a series of preliminary spent fuel tests was performed. A new method for providing improved data on Np concentrations with EELS was tested on a series of mineral phases.

The development of a set of standards for the Yucca Mountain Program to improve future Np analyses with analytical techniques would be beneficial.

\section{References}

EC Buck, RJ Finch, PA Finn, and JK Bates. 1998. "Retention of neptunium in uranyl alteration phases formed during spent fuel corrosion." Mater. Res. Soc. Symp. Proc. 506:87-94. 


\section{Acronyms}

$\begin{array}{ll}\text { ANL } & \text { Argonne National Laboratory } \\ \text { ATM } & \text { Approved Testing Material } \\ \text { CSNF } & \text { Commercial Spent Nuclear Fuel } \\ \text { EDS } & \text { Energy Dispersive X-Ray Spectroscopy } \\ \text { EELS } & \text { Electron Energy-Loss Spectroscopy } \\ \text { EMSL } & \text { Environmental Molecular Sciences Laboratory } \\ \text { IR } & \text { Infrared Spectroscopy } \\ \text { KPA } & \text { Kinetic Phosphorescence Analysis } \\ \text { ICM-MS } & \text { Inductively Coupled Plasma-Mass Spectrometry } \\ \text { IR } & \text { Infrared } \\ \text { ORIGEN2 } & \text { Isotope Generation and Depletion Code } \\ \text { PEELS } & \text { Parallel EELS } \\ \text { PNNL } & \text { Pacific Northwest National Laboratory } \\ \text { SEM } & \text { Scanning Electron Microscopy } \\ \text { TEM } & \text { Transmission Electron Microscope } \\ \text { TRU } & \text { Transuranic } \\ \text { XAS } & \text { X-Ray Absorption Spectroscopy } \\ \text { XRD } & \text { X-Ray Diffraction }\end{array}$

\section{Definitions}

Absorption Is generated at an energy where the scattering probability jumps due to an ionizing

Edge transition.

Alteration A phase formed following corrosion of the primary phase.

Phase

$\mathbf{M}_{4,5}$-Edges Resulting from transitions from $3 d$ level to unoccupied $5 f$ levels and continuum states.

Plural In EELS, occurs when an electron passing through sample undergoes multiple scattering Scattering events. The resultant energy-loss signal is the sum of inelastic losses.

Spectrum In this report, refers to a plot of measured intensity versus electron or x-ray energy. 


\section{Mineral Names and Formulae used in the Report}

\begin{tabular}{|c|c|}
\hline MINERAL NAME & FORMULA \\
\hline Boltwoodite & $\mathrm{K}_{2}\left(\mathrm{UO}_{2}\right)_{2}\left(\mathrm{SiO}_{3}\right)_{2}(\mathrm{OH})_{2} \cdot 5 \mathrm{H}_{2} \mathrm{O}$ \\
\hline Compreignacite & $\mathrm{K}_{2} \mathrm{O} \bullet 6 \mathrm{UO}_{2} \bullet 11 \mathrm{H}_{2} \mathrm{O}$ \\
\hline Dehydrated Schoepite & $\mathrm{UO}_{3} \bullet 0.8 \mathrm{H}_{2} \mathrm{O}$ \\
\hline Meta-Schoepite & {$\left[\left(\mathrm{UO}_{2}\right)_{8} \mathrm{O}_{2}(\mathrm{OH})_{12}\right]\left(\mathrm{H}_{2} \mathrm{O}\right)_{6}$} \\
\hline Meta-Studtite & {$\left[\mathrm{UO}_{2}\left(\mathrm{O}_{2}\right)\left(\mathrm{H}_{2} \mathrm{O}\right)_{2}\right]\left(\mathrm{H}_{2} \mathrm{O}\right)$} \\
\hline Soddyite & $\left(\mathrm{UO}_{2}\right)_{5}\left(\mathrm{SiO}_{4}\right)_{2}(\mathrm{OH})_{2} \cdot 5 \mathrm{H}_{2} \mathrm{O}$ \\
\hline Studtite & {$\left[\mathrm{UO}_{2}\left(\mathrm{O}_{2}\right)\left(\mathrm{H}_{2} \mathrm{O}\right)_{2}\right]\left(\mathrm{H}_{2} \mathrm{O}\right)_{2}$} \\
\hline Uraninite & $\mathrm{UO}_{2}$ \\
\hline Uranophane & $\mathrm{Ca}\left(\mathrm{UO}_{2}\right)_{2}\left(\mathrm{SiO}_{3}\right)_{2}(\mathrm{OH})_{2} \cdot 5 \mathrm{H}_{2} \mathrm{O}$ \\
\hline Weeksite & $\mathrm{K}_{2}\left(\mathrm{UO}_{2}\right)_{2}\left(\mathrm{Si}_{2} \mathrm{O}_{5}\right)_{3} \bullet 4 \mathrm{H}_{2} \mathrm{O}$ \\
\hline
\end{tabular}

\section{Unit Abbreviations}

$\begin{array}{ll}\begin{array}{l}\text { at } \% \\ { }^{\circ} \mathrm{C}\end{array} & \begin{array}{l}\text { Atomic percent } \\ \mathrm{cm}^{-1}\end{array} \\ \mathrm{eV} & \text { wagrees Centigrade } \\ \mathrm{g} & \text { electron volt } \\ \mathrm{keV} & \text { kram } \\ \mu \mathrm{g} & \text { microgram } \\ \mu \mathrm{m} & \text { micrometer } \\ \mathrm{M} & \text { molarity / mole } \\ \mathrm{mg} & \text { milligram } \\ \mathrm{mL} & \text { milliliter } \\ \mathrm{nm} & \text { nanometer } \\ \mathrm{wt} \% & \text { weight percent }\end{array}$




\section{Acknowledgements}

The transmission electron microscopy work was performed at the Environmental Molecular Sciences Laboratory, a national scientific user facility sponsored by DOE's Office of Biological and Environmental Research and located at Pacific Northwest National Laboratory, operated for DOE by Battelle under Contract DE-AC06-76RL01830. 


\section{Contents}

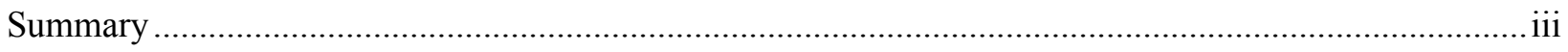

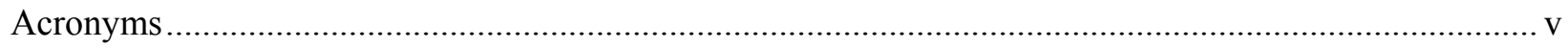

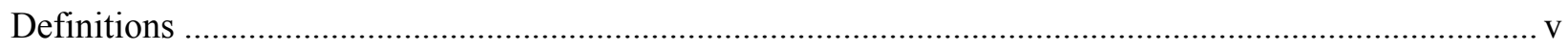

Mineral Names and Formulae used in the Report.............................................................................. vi

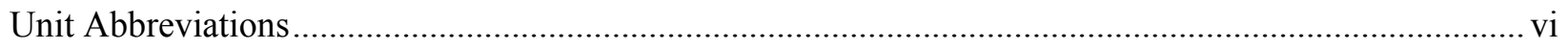

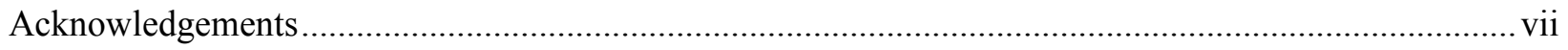

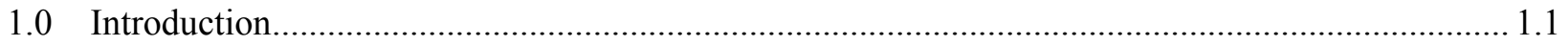

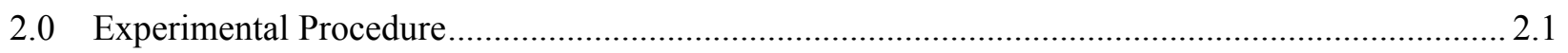

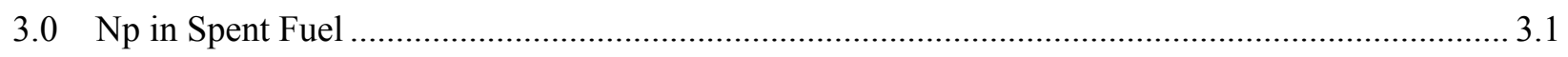

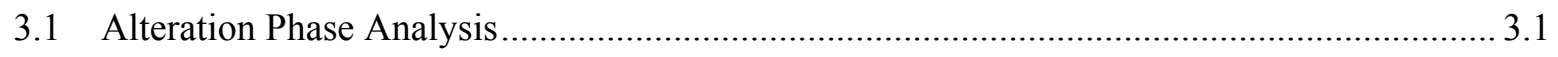

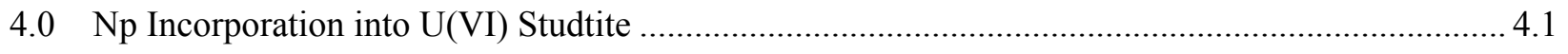

4.1 Analysis of Laboratory-Synthesized Np-Doped Studtite ................................................ 4.1

4.2 Analysis of Np Incorporation into Uranophane................................................................. 4.4

4.3 Analysis of Spent Fuel Studtite Phases ......................................................................... 4.6

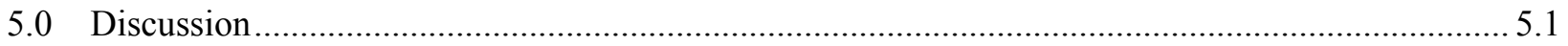

5.1 Effect of Oxidation Potential on $\mathrm{Np}$ behavior ................................................................... 5.1

5.2 Retention of Np during Borosilicate Glass Dissolution.................................................. 5.1

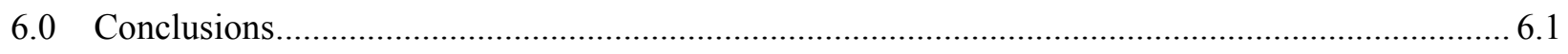

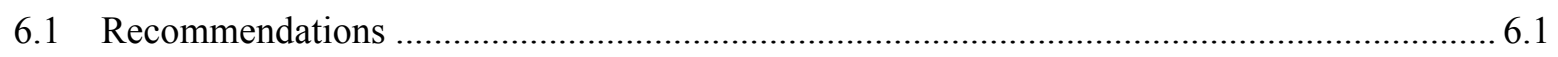

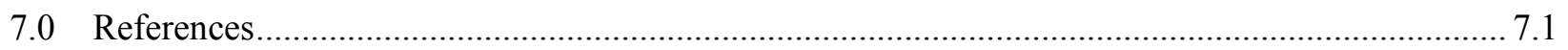




\section{Figures}

2.1. Standard Sample Containing $\mathrm{U}, \mathrm{Np}$, and $\mathrm{Pu}$

3.1. EELS of CSNF Material Showing Separation of $184 \mathrm{eV}$ Between the Two Features Corresponding to the $\mathrm{Np}-\mathrm{M}_{5}$ and $\mathrm{Np}-\mathrm{M}_{4}$ Peaks

3.2. EELS of CSNF Material Showing Separation of $184 \mathrm{eV}$ Between the Two Features Corresponding to the $\mathrm{Np}-\mathrm{M}_{5}$ and $\mathrm{Np}-\mathrm{M}_{4}$ Peaks

3.3. Two Identical Spectra, Except that One (the solid line) Has Been Shifted Exactly $176 \mathrm{eV}$

3.4. Comparison of Plural Scattering Peaks from a thick U-Only Sample and the Np Spectrum from 2.1

3.5. (a) Data Present in Buck et al. (1998) and (b) Obtained from Alteration Phases in a CSNF Sample

3.6. Electron Energy-Loss Spectra of a Uranyl Alteration Phase, Showing an Energy Separation that is Consistent with Np Being Associated with the Phases (red-line)......

4.1. (a) Simulated Spectra of Np-Doped Studtite and (b) Experimental Analysis of Doped Solid........ 4.2

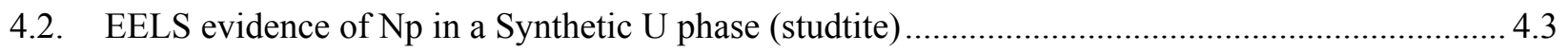

4.3. Infrared Spectrum of Studtite and Np-Studtite (KBr Pellet) ........................................................ 4.3

4.4. Optical Images of Uranophanes (a) Non-doped and (b) Np-Doped Uranophanes ........................ 4.4

4.5. Screen Shots from the Gatan Program EL/P Showing the $\sim 176-\mathrm{eV}$ Window Between the U M-Edges and the $\sim 189$-eV Window Between the Np M-edges

4.6. Electron Energy-Loss Spectrum of Uranophane Solid Containing Low and high Concentrations of $\mathrm{Np}$.

4.7. (a) Low Magnification SEM Picture of Meta-Studtite Released from the Surface of Corroded Spent Nuclear Fuel and (b) Higher Magnification Image Showing an Individual Crystallite. The drying in the microscope vacuum chamber may have resulted in the cracking in the particles. (c) X-ray diffraction scan of studtite.

5.1. Normalized Mass Losses of U/Np for SRL131A and SRL202A Glasses Reacted at $20,000 \mathrm{~m}^{-1}$ (extracted from Ebert [1995]). 


\section{Tables}

2.1. Absorption Edge Energies ${ }^{(\mathrm{a})}$ for Actinide Elements (values in $\mathrm{eV}$ ) ...........................................2.2

4.1. Radiochemical Analysis of Dried Films from SNF after 1.5 Years of Immersion ...................... 4.8

4.2. Radiochemical Analysis of Leachates from SNF after 1.5 Years of Immersion.......................... 4.8 


\subsection{Introduction}

Many countries, including those with active fuel-reprocessing facilities, are planning to dispose of commercial spent nuclear fuel (CSNF) from nuclear reactors. The CSNF may be either sent to a permanent geologic repository or to an interim storage facility. It is unlikely that all water can be completely removed from the CSNF casks; in addition, over time, some casks are expected to fail, allowing small amounts of water to contact the fuel. Due to its high radiation field, CSNF in contact with water may undergo oxidative dissolution under both oxidizing and reducing environments by the formation of reactive radiolysis products. Dissolution of natural uraninite $\left(\mathrm{UO}_{2}\right)$ (Finch and Ewing 1992) and synthetic $\mathrm{UO}_{2}$ (Wronkiewicz et al. 1992) can result in the formation of a series of U(VI) secondary phases, such as uranyl oxide hydrates (e.g., meta-schoepite), uranyl silicates (e.g., uranophane), phosphates, or carbonates, depending on the composition of the contacting water. However, in CSNF, less is known about the fate of the fission and neutron capture products that may result in the precipitation of unique alteration phases, depending on the availability of these species in the fuel matrix. Burns et al. (1997) have theorized that many of the U(VI) alteration phases may be capable of incorporating several key radionuclides, including neptunium $(\mathrm{Np})$, technetium $(\mathrm{Tc})$, and plutonium $(\mathrm{Pu})$. Cesium $(\mathrm{Cs})$, barium $(\mathrm{Ba})$, and molybdenum (Mo) have been observed to be incorporated into a unique U(VI) phase related to billietite (Buck et al. 1997).

This study examines existing data on $\mathrm{Np}$ behavior from both spent fuel and glass tests in an effort to resolve some issues concerning the selection of possible solubility limiting phases for $\mathrm{Np}$ and the methods for detecting $\mathrm{Np}$ at low levels in spent fuel. This report examines the ability of Electron Energy-Loss Spectroscopy (EELS) on the Transmission Electron Microscope (TEM) to detect low levels of neptunium $(\mathrm{Np})$ in a uranium matrix and in the possible presence of rare earth and transuranic elements. Verification of this technique is necessary to support the case for using uranium (VI) secondary minerals from corroded spent fuel as the solubility-controlling phases for $\mathrm{Np}$ in the Yucca Mountain performance assessment model. In this report, the application of EELS to detect $\mathrm{Np}$ at low levels in uranium phases is examined through analysis of data from spent fuel tests and synthesis tests. Because TEM-EELS is a high spatial resolution technique it provides one of the most suitable methods for probing the nature of sub-micron multiphase solids, such as those formed during the corrosion of spent fuel.

A major problem with the analysis of CSNF with any elemental-analysis method is that the level of many key elements is at or below detection limits. Techniques that typically have sufficient limits of detection may not have the required spatial resolution to examine the nano-sized corrosion products of CSNF. It is possible to establish the association of $\mathrm{Np}$ or other elements with a particular $\mathrm{U}$ phase, but only a microscopy technique with high spatial resolution can be used to determine whether the element is incorporated into the phase of interest.

The work with CSNF and borosilicate glass with EELS has allowed the detection of rare-earth elements and the major actinide (Pu) (Buck and Fortner 1997; Buck 1999). The detection of Np is important to establish that its long-term behavior is necessary for developing models. 


\subsection{Experimental Procedure}

The CSNF used in this study was Approved Testing Material (ATM)-106, ATM-103, and ATM-101 with average burn-ups of 45, 33, and $31 \mathrm{MWd} / \mathrm{kgU}$, respectively (Guenther et al. 1986). Tests run at Argonne National Laboratory (ANL) used spent-fuel fragments placed on a Zircaloy retainer inside a steel test vessel exposed to moderate amounts of water (Finn et al. 1994). The atmosphere in the reaction vessel was limited in oxygen; however, the radiation field generated by the fuel itself produced an oxidizing environment. In tests at Pacific Northwest National Laboratory (PNNL), ATM-101 was reacted with deionized water for periods up to two years. In addition, laboratory synthesis of neptunium-doped U(VI) phases was carried out at PNNL (Douglas et al. 2003). These phases were examined with electron microscopy, $\mathrm{x}$-ray diffraction, and infrared spectroscopy. The results of EELS examinations are reported here.

During a limited number of sampling periods during the drip tests at ANL, random samples of corroded spent fuel were extracted from the test vessel and examined with optical and scanning electron microscopy. Given the nature of the sample preparation process and the difficulty of extracting samples in a hot cell, it is not possible to know whether these selected particles were representative of the entire sample. Micron-sized particles from these extracted particles were then embedded in an epoxy resin and thin-sectioned with an ultramicrotome. The electron-transparent thin-sections of the corroded spent fuel were laid on 200-mesh carbon-coated copper grids and examined with a 200-keV transmission electron microscope with an attached Gatan Image Filter (GIF) for electron energy-loss spectroscopy and an x-ray energy dispersive spectrometer. The EELS energy resolution was 1.5 to $2.0 \mathrm{eV}$ at the M-edges of the rare earth elements (REE) and 4 to $5 \mathrm{eV}$ at the M-edges of the transuranics (TRUs).

The initial investigations were performed with a Gatan parallel EELS (PEELS) system and later with the much more efficient Gatan Image Filter (GIF200) attached to a JEOL2000FXII Transmission Electron Microscope (TEM) at ANL and the JEOL2010 TEM with attached GIF2000 image filter at the Environmental Molecular Sciences Laboratory (EMSL) at PNNL. Two techniques were used to confirm the presence of elements in the fuel samples, the peak position based on values reported in the literature, and the peak-to-peak separation. Analyses were performed with second difference imaging, using a unique script within the Gatan, Inc. software for this purpose (Buck 1999). Second-difference spectroscopy requires three spectra to be collected in series offset by a set energy difference, typically equal to the peak width (4 to $6 \mathrm{eV}$ ). Electron energy-loss spectroscopy can detect rare-earth elements at ppm levels in spent fuel (Buck 1999). The absorption edges are often displaced 3 to $5 \mathrm{eV}$ from the nominal positions reported in the literature, possibly due to changes in the chemistry of the analyzed elements (See Table 2.1).

During two sampling periods (44 and 48 months), random samples of corroded spent fuel were extracted from the Argonne CSNF unsaturated test vessels and examined. Given the nature of the samplepreparation process and the difficulty of extracting samples, it was not possible to know whether these selected particles were representative of the entire sample. Micron-sized particles from these extracted particles were then embedded in an epoxy resin and thin-sectioned with an ultramicrotome. The electrontransparent thin-sections of the corroded spent fuel were laid on 200 mesh carbon-coated copper grids and examined.

Of particular interest in the actinide series is the detection of $\mathrm{Np}$. $\mathrm{Np}$ is characterized by two sharp M-edges at $3665 \mathrm{eV}\left(\mathrm{M}_{5}\right)$ and $3850 \mathrm{eV}\left(\mathrm{M}_{4}\right)$; however, the $\mathrm{Np}-\mathrm{M}_{5}$ "white-line" is nearly coincident with a plural scattering peak from $U$ (see Table 2.1). This additional peak is the result of a $U_{-} \mathrm{O}_{4,5}(\sim 95$ to 113 $\mathrm{eV}$ ) event combined with the $\mathrm{U}-\mathrm{M}_{5}$ edge at $3552 \mathrm{eV}$, resulting in a broad ( $\sim 12$ to $\left.18 \mathrm{eV}\right)$ peak near 3665 $\mathrm{eV}$. However, the Np-M $\mathrm{M}_{4}$ peak is not subject to similar interference and is separated from the plural event 
on the $\mathrm{U}-\mathrm{M}_{4}$ edge by 7 to $8 \mathrm{eV}$. Hence, the method adopted in this study has been to look for evidence of the $\mathrm{Np}-\mathrm{M}_{4}$ peak and its separation from the more intense peak typically observed near $3665 \mathrm{eV}$. All spectra were calibrated internally from the assumed $176-\mathrm{eV}$ energy separation of the $\mathrm{U}_{5}$ and $\mathrm{M}_{4}$ edges. The separation of the $\mathrm{M}_{4}$ and $\mathrm{M}_{5}$ edges for $\mathrm{U}, \mathrm{Pu}$, and $\mathrm{Np}$ was checked using a standard sample with large concentrations of these particular elements (see Figure 2.1). The energy separation agrees with literature values.

The plural effect was clearly visible in many collected U spectra; however, its effect was reduced by using very thin samples, optimizing the energy resolution, and reducing counting times. Reducing the energy dispersion will also allow more accurate separation of features near both Np-M edges by increasing the number of channels between the features. However, if the energy width of the U-M 'white-lines' is larger than $8 \mathrm{eV}$, it may be impossible to distinguish plural events from absorption edges.

Table 2.1. Absorption Edge Energies ${ }^{(a)}$ for Actinide Elements (values in eV)

\begin{tabular}{||c|c|c|c|c|c|c||}
\hline & $\mathbf{N}_{\mathbf{5}}$ & $\mathbf{N}_{\mathbf{4}}$ & $\left.\Delta \mathbf{E} \mathbf{( N}_{\mathbf{4 , 5}}\right)$ & $\mathbf{M}_{\mathbf{5}}$ & $\mathbf{M}_{\mathbf{4}}$ & $\begin{array}{c}\Delta \mathbf{E} \\
\left(\mathbf{M}_{\mathbf{4 , 5}}\right.\end{array}$ \\
\hline $\mathrm{Th}$ & 676 & 714 & 38 & 3332 & 3491 & 159 \\
\hline $\mathrm{U}$ & 738 & 780 & 42 & 3552 & 3728 & 176 \\
\hline $\mathbf{N p}$ & $\mathbf{7 7 0}$ & $\mathbf{8 1 6}$ & $\mathbf{4 6}$ & $\mathbf{3 6 6 6}$ & $\mathbf{3 8 5 0}$ & $\mathbf{1 8 4}$ \\
\hline $\mathrm{Pu}$ & 801 & 850 & 49 & 3778 & 3973 & 196 \\
\hline $\mathrm{Am}$ & 828 & 879 & 51 & 3887 & 4092 & 205 \\
\hline
\end{tabular}

(a) Data taken from the Handbook for Chemistry and Physics, $63^{\text {rd. }}$ Edition, 1982-1983, CRC Press. 
Bank: I

Memory:a b c d e f Y Z

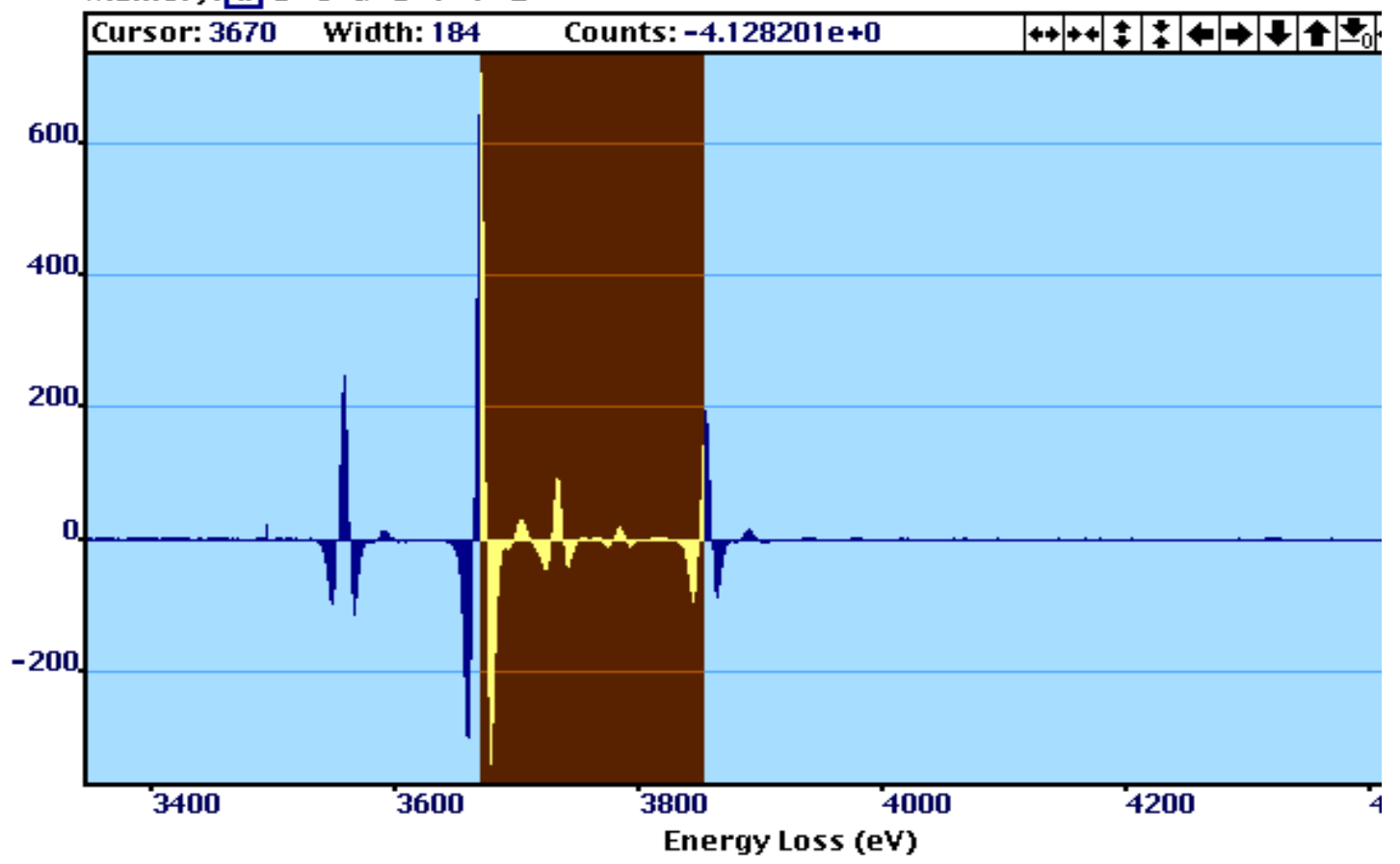

Figure 2.1. Standard Sample Containing U, Np, and Pu. The window shows the energy separation between the $\mathrm{Np}-\mathrm{M}_{5}$ and $\mathrm{Np}-\mathrm{M}_{4}$ edges of $184 \mathrm{eV}$. The spectrum has been collected in second difference mode on a Gatan Image Filter. 


\subsection{Np in Spent Fuel}

As the plural scattering peak from $\mathrm{U}$ overlaps in the region where we expect to observe the $\mathrm{Np}-\mathrm{M}_{5}$ edge, we have used the expected separation in energy between the two intense M-edges from Np. Figure 3.1 through Figure 3.3 shows the separation of two weak features from a sample of CSNF. An energy window $184 \mathrm{eV}$ wide demonstrates the separation. A plural peak on the $\mathrm{U} \mathrm{M}_{4}$ edge would be separated from the $\mathrm{Np}-\mathrm{M}_{4}$ peak by $8 \mathrm{eV}$. Indeed, this peak is observed in $\mathrm{Np}$-free spectra and is separated from the lower energy plural peak by $176 \mathrm{eV}$. If the energy resolution obtained is sufficient, it should be possible to distinguish plural events from the actual presence of $\mathrm{Np}$ using the higher energy M-edge.

Another piece of evidence comes from comparing the intensity ratios of the two features in the $\mathrm{Np}$ spectrum. This is reported as the $\mathrm{M}_{4} / \mathrm{M}_{5}$ intensity ratio. If the features are entirely due to plural scattering, then the intensity ratio of the plural peak should be the same as the intensity ratio of the $\mathrm{U}-\mathrm{M}_{4} / \mathrm{M}_{5}$ peaks (0.45). For the pure standard Np sample (see Figure 2.1), the $\mathrm{M}_{4} / \mathrm{M}_{5}$ ratio is close to 0.28. From three analyses of $\mathrm{Np}$ features in actinide EELS spectra, ratios of $0.3,0.28$, and 0.3 were observed.

The intensity ratio of the $\mathrm{U}-\mathrm{M}_{4} / \mathrm{M}_{5}$ is 0.46 and is equal to the intensity ratio of the plural peaks. The separation between the two plural peaks is $176 \mathrm{eV}$. The effect of superimposing a pure U-M spectrum on itself and shifting by $176 \mathrm{eV}$ results in a perfect overlap at the plural peak position. The fact that a similar operation on the spectrum shown in Figure 3.1 through Figure 3.3 results in a resolvable separation of near $8 \mathrm{eV}$ is proof that $\mathrm{Np}$ can be detected with EELS at low levels. In Figure 3.4, an Np spectrum has been overlaid on a U-only spectrum. The plural peaks are visible as broad humps. The $\mathrm{Np}-\mathrm{M}_{4}$ edge does not match with the plural hump from the U.

\subsection{Alteration Phase Analysis}

A major issue is whether there is any evidence of Np incorporation into alteration phases in the CSNF tests. In Figure 3.5, EELS analysis of an alteration phase from the ANL drip tests is shown. Further evidence is shown in the spectra in Figure 3.6. In this case, a 176-eV window does not match the two features on the spectrum; however, a window of $184 \mathrm{eV}$ does resolve this issue.

The window between the two features is near the assumed positions for $\mathrm{Np}-\mathrm{M}_{5}$ and $\mathrm{Np}-\mathrm{M}_{4}$. If the features were entirely due to plural scattering, the peak-to-peak separation would not be near $184 \mathrm{eV}$. This is proof that, at least in this case, $\mathrm{Np}$ is most likely present in the phase. Spectrum has been superimposed on itself and shifted by $176 \mathrm{eV}$. The separation is near $6 \mathrm{eV}$, not the ideal value of $7.5 \mathrm{eV}$, but this is further evidence that the peaks are not solely due to plural scattering and that the phase likely contains $\mathrm{Np}$. 


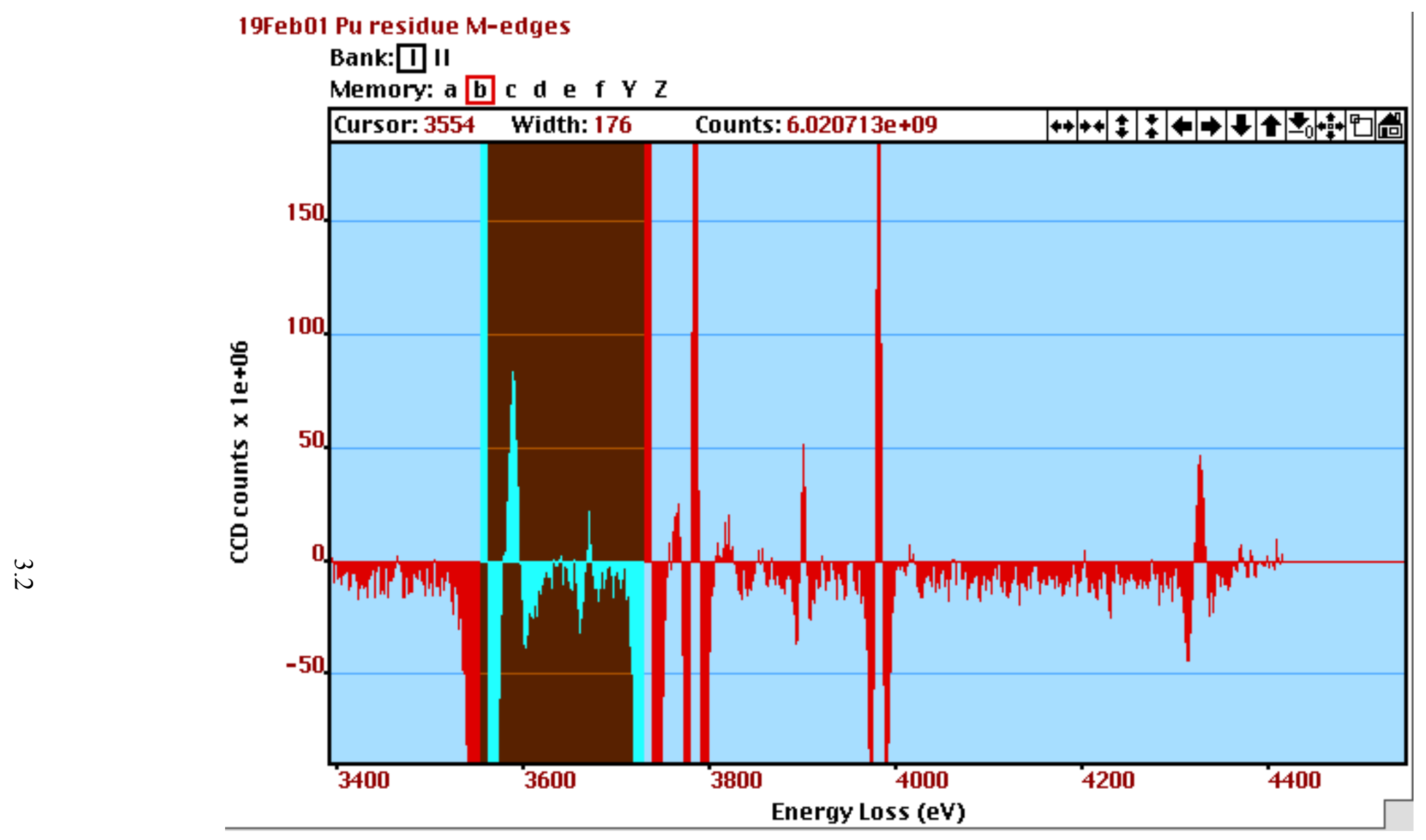

Figure 3.1. EELS of CSNF Material Showing Separation of $184 \mathrm{eV}$ Between the Two Features Corresponding to the Np$\mathrm{M}_{5}$ and Np-M 4 Peaks 


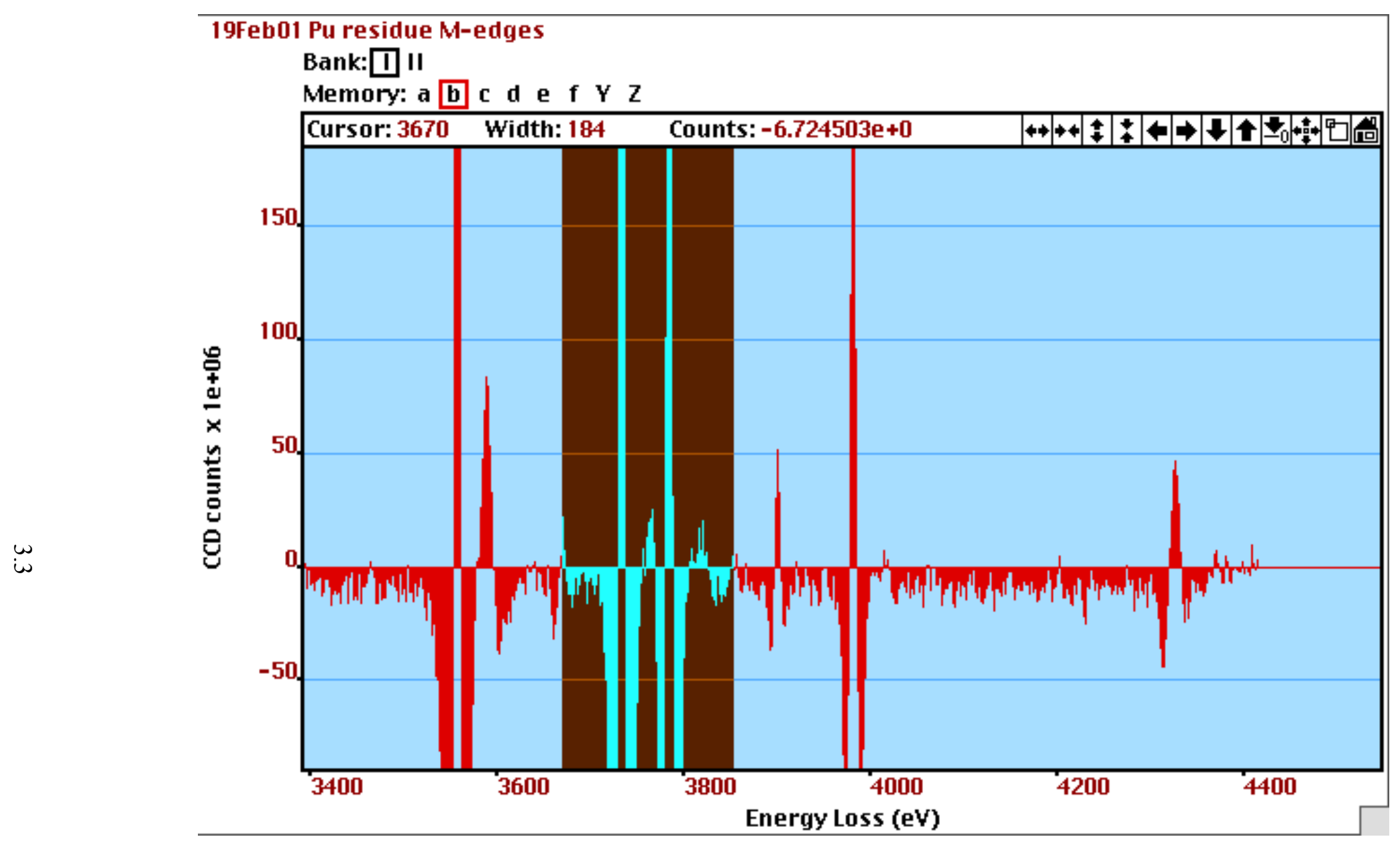

Figure 3.2. EELS of CSNF Material Showing Separation of $184 \mathrm{eV}$ Between the Two Features Corresponding to the Np$\mathrm{M}_{5}$ and $\mathrm{Np}-\mathrm{M}_{4}$ Peaks 


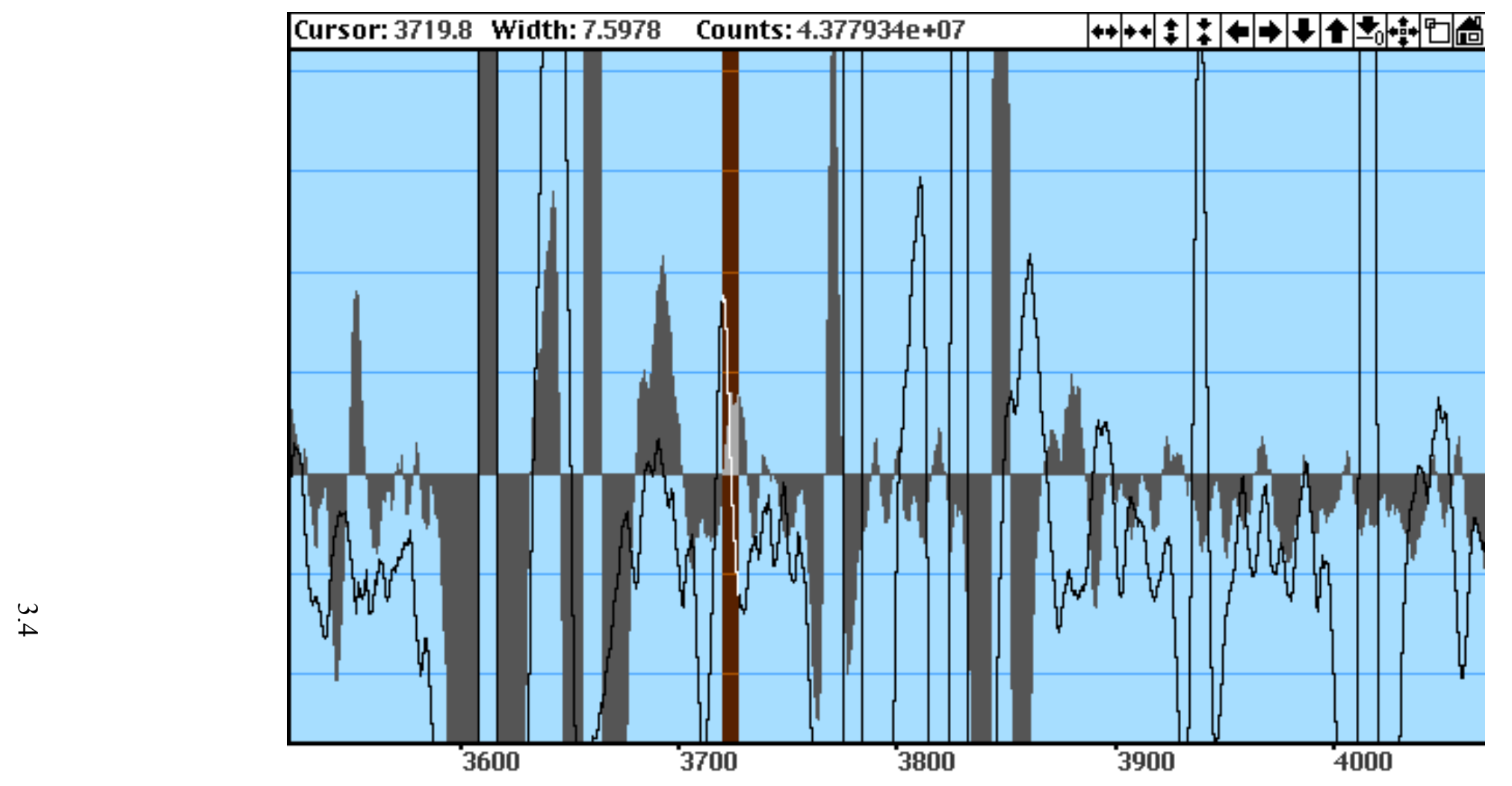

Figure 3.3. Two Identical Spectra, Except that One (the solid line) Has Been Shifted Exactly $176 \mathrm{eV}$. The U-M $\mathrm{M}_{4}$ edge of one spectrum has been superimposed on the $U-M_{5}$ of the other spectrum. A window has been drawn over the separation between two features in the spectrum. This window is $7.6 \mathrm{eV}$ wide and corresponds to the $\mathrm{Np}^{-\mathrm{M}_{4}}$ energy $(3850 \mathrm{eV})$ minus the $\mathrm{Np}-\mathrm{M}_{5}$ energy (3665) - 176 (the shift energy). If both peaks were due entirely to plural scattering of the $\mathrm{U}$, then they would overlay exactly. This is proof that $\mathrm{Np}$ is being detected in this spectrum. 
In Figure 3.5a, the measured peak-to-peak separation is $178 \mathrm{eV}$ for the $\mathrm{U}$ and $182 \mathrm{eV}$ for the "Np" regions. This gives a calibrated energy of about $180 \mathrm{eV} \pm 1 \mathrm{eV}$. In Figure 3.5b, the data were collected on a PEELS system. The total counts $(20,000+)$ in the $\mathrm{Np}-\mathrm{M}_{5}$ region suggest that a visible peak should be present after the $\mathrm{U}_{-} \mathrm{M}_{4}$ if plural scattering is the dominant process. However, the lack of a distinguishable peak in the $\mathrm{Np}-\mathrm{M}_{4}$ can be explained from chemical considerations. The intensity of the $\mathrm{Np} \mathrm{M}_{4}$ edge is much lower than for the earlier actinides in the series. This tends to support the assertion that Np can be detected and is in some uranyl phases.

The spectrum obtained from the uranium (VI) phase, weeksite [ideally $\mathrm{K}_{2}\left(\mathrm{UO}_{2}\right)_{2}\left(\mathrm{Si}_{2} \mathrm{O}_{5}\right)_{3} \bullet 4 \mathrm{H}_{2} \mathrm{O}$ ], was run through a peak fitting program to obtain more reliable estimates of the peak energies and the peak separation. These estimates are consistent with the values obtained with the EELS program and support the assertion that $\mathrm{Np}$ is incorporated into the weeksite phase (Buck and Fortner 1997). It is possible to calibrate spectra accurately by comparing them against the $\mathrm{Np}$ standard spectrum that is shown in Figure 2.1. The U-M edges from two alteration-phase spectra have been matched against the U-M edges on the $\mathrm{Np}$ standard sample (this phase contained $\mathrm{Np}, \mathrm{U}$, and trace $\mathrm{Pu}$ ) (see Figure 3.6). The green-line of the $\mathrm{Np}$ standard spectrum lines perfectly with that from the blue spectrum (uranyl alteration phase) but not as well with the red. Again, if the peaks were entirely due to plural scattering, the match would not be made.

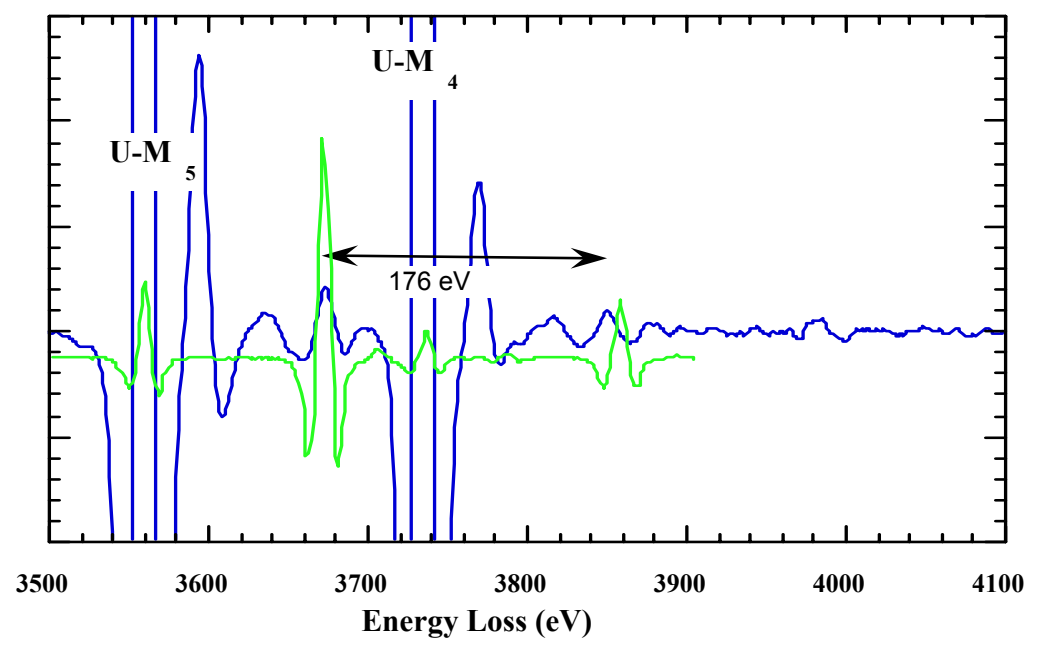

Figure 3.4. Comparison of Plural Scattering Peaks from a thick U-Only Sample and the Np Spectrum from Figure 2.1 
a

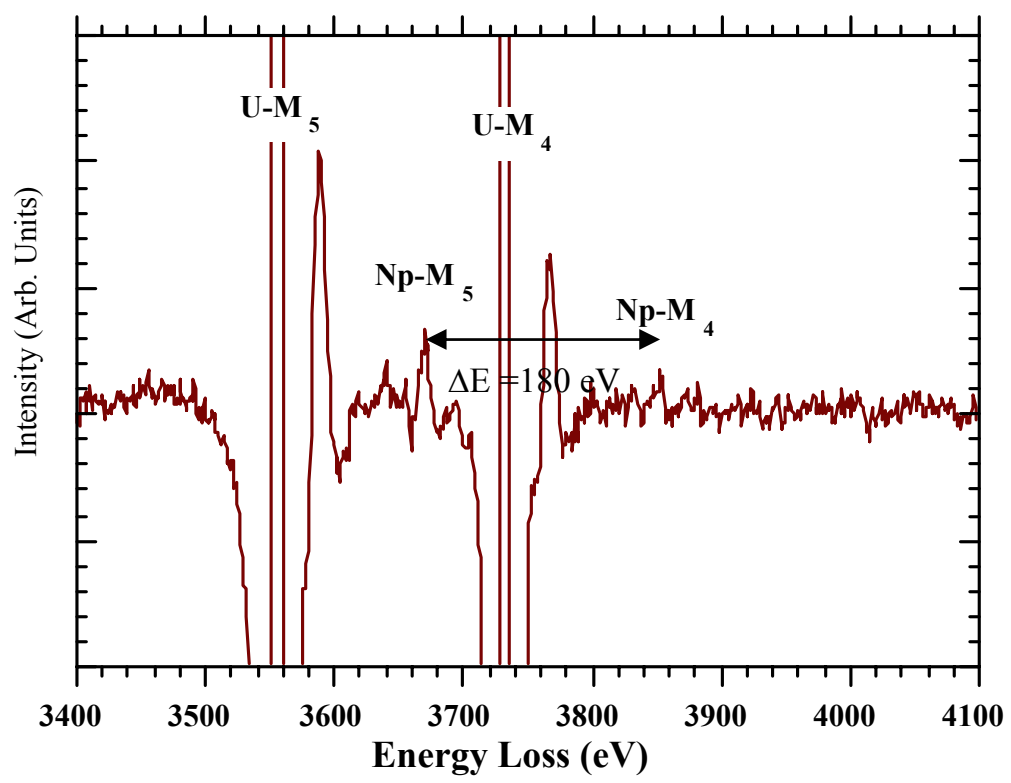

b

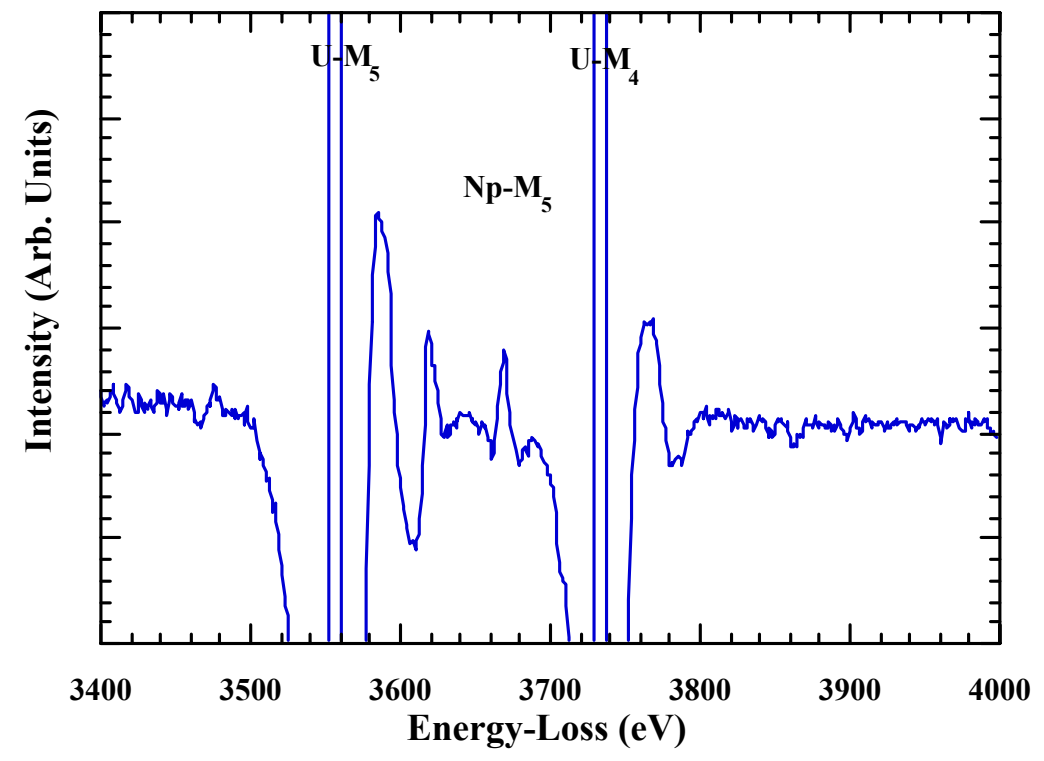

Figure 3.5. (a) Data Present in Buck et al. (1998) and (b) Obtained from Alteration Phases in a CSNF Sample 


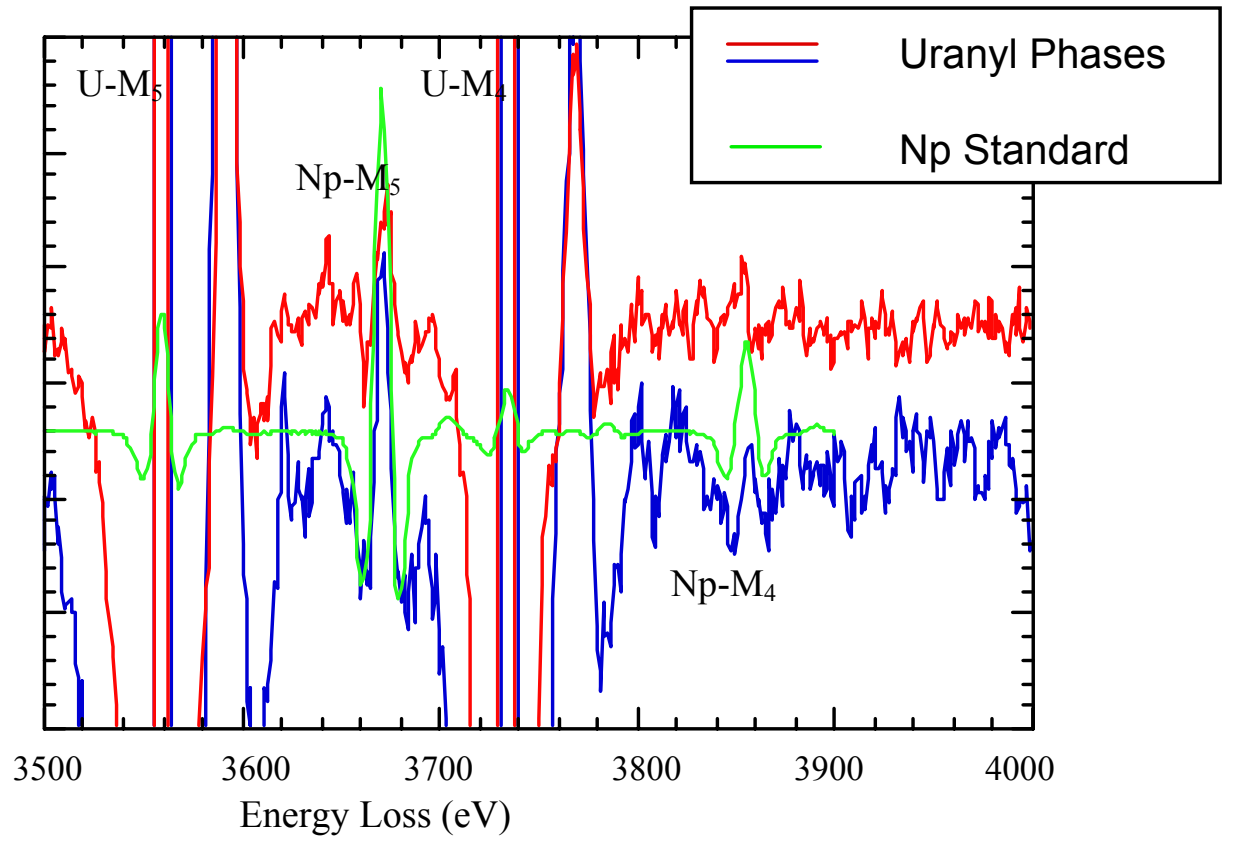

Figure 3.6. Electron Energy-Loss Spectra of a Uranyl Alteration Phase, Showing an Energy Separation that is Consistent with Np Being Associated with the Phases (red-line). Data obtained from a CSNF corrosion test (blue line). Obtained from an SRL131A glass test. The M4,5 edge energy separation on the $\mathrm{Np}$ standard (green line) was $184.4 \mathrm{eV}$. 


\subsection{Np Incorporation into U(VI) Studtite}

The fundamental problem addressing the issue of $\mathrm{Np}$ behavior in weathered waste forms is the low level of Np in the starting material. The CSNFs tested have about 400 to $600 \mathrm{ppm} \mathrm{Np}$. This is below the limit of detection of energy dispersive x-ray spectrometry (EDS) systems on TEMs and scanning electron microscopy (SEMs) because of low signal-to-noise and overlap problems with the many other elements in spent fuels. Although radiochemical methods, inductively coupled plasma-mass spectrometry (ICP-MS) methods, and X-ray absorption spectroscopy (XAS) with a Synchrotron source do have the capability of detecting such levels of $\mathrm{Np}$ in spent fuel, the low spatial resolution of these methods together with relatively imprecise sampling means that we will not be able to determine the disposition of $\mathrm{Np}$ in any alteration phase with these techniques. To date, the only method available is EELS on a TEM. However, this technique is extremely difficult because of the specific energy region that must be used. To date, only a few examples of possible $\mathrm{Np}$ incorporation into an alteration phase have been found. Although these data have been widely used to support the concept of Np incorporation, there has been little experimental evidence from spent-fuel tests on $\mathrm{Np}$ incorporation into uranyl alteration phases (e.g., $\beta$ uranophane and boltwoodite). However, even if unequivocal evidence for $\mathrm{Np}$ incorporation had been found in the Argonne tests, would this be valid for a repository model? As these tests were only carried out under one set of conditions, they may not be valid for all water chemistries.

\subsection{Analysis of Laboratory-Synthesized Np-Doped Studtite}

A Np-doped studtite was prepared and then examined the solid with X-ray diffraction (XRD) and TEM. The starting $\mathrm{Np}$ was held in the (V) oxidation state with $\mathrm{NaNO}_{2}$. Ultra-violet spectroscopy was used to establish the oxidation state. Uranyl nitrate $(0.5 \mathrm{~g})$ was reacted with $1 \mathrm{M} \mathrm{H}_{2} \mathrm{O}_{2}$. The resultant product in the U-only test was a light yellow white solid, consistent with studtite. To produce the Np-bearing $\mathrm{U}$ solid, we added the $\mathrm{Np}(\mathrm{V})$ solution to the reacting uranyl nitrate solution.

The resulting solid that precipitated was red-brown (the pure U studtite was white). A green coloration remained in the solution, indicating the presence of some residual $\mathrm{Np}(\mathrm{V})$. Characterization of the $\mathrm{U}$ phase and $\mathrm{Np}$-doped U phase was performed with optical microscopy, XRD, infrared (IR), and TEM.

In Figure 4.1a, an example of an EDS spectrum of the U solid is shown. It was not possible to quantify the amount of Np present, as standards were not available, but it appears to be around $10 \%$ of the U based on EDS simulations (see Figure 4.1b). The EDS results demonstrate how difficult it is to detect Np even at relatively high levels; however, with a complete set of standards, it should be possible to model the peak shapes, allowing lower detection limits. In contrast, EELS was easily able to detect this level of $\mathrm{Np}$ in the solid. The sample used was not ideal for EELS (see Figure 4.2). 


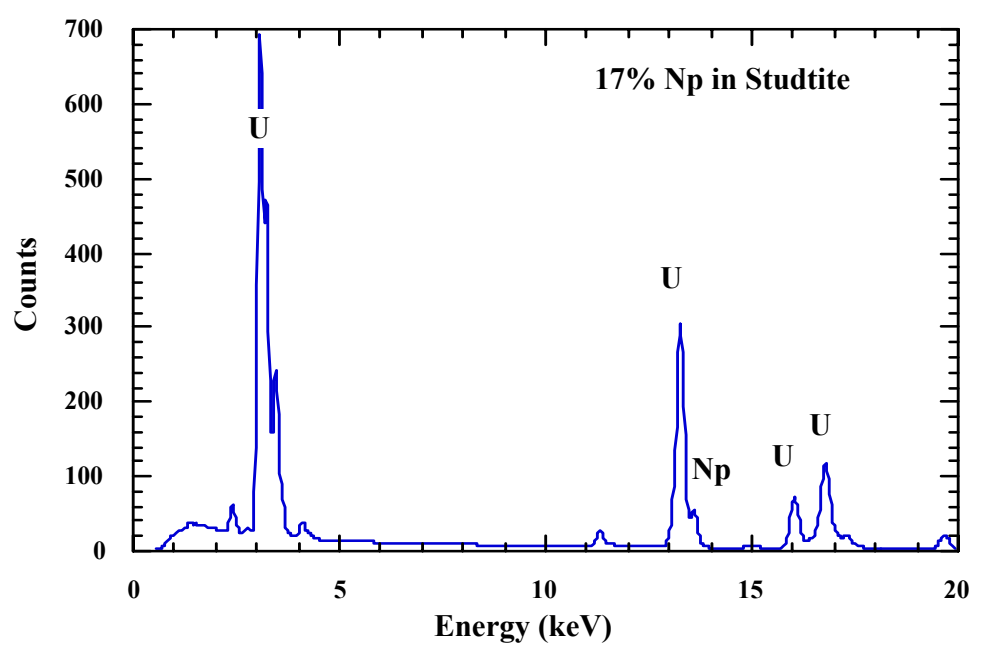

(a)

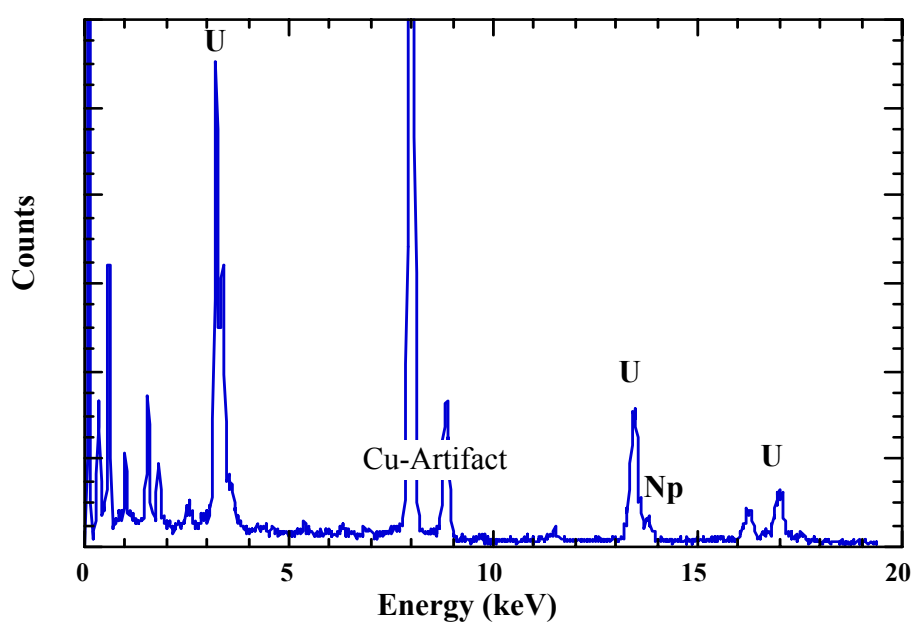

(b)

Figure 4.1. (a) Simulated Spectra of Np-Doped Studtite and (b) Experimental Analysis of Doped Solid

The EELS analysis is the best evidence for incorporating Np into this phase. The actinide N-edges were analyzed, and although they are very weak, they are at a lower energy and easier to obtain in radiationsensitive materials. X-ray diffraction of the U phase and the Np-doped material were both consistent with studtite. No other minor phases were detected.

Further evidence for the purity of the $\mathrm{U}$ and Np-doped solids was obtained from IR spectroscopy (see Figure 4.3). Both IR spectra are similar and show several interesting features. The spectrum in the 3000 to $3500 \mathrm{~cm}^{-1}$ region is characteristic of bonded water and typical of the layered uranyl (VI) oxide phases. 


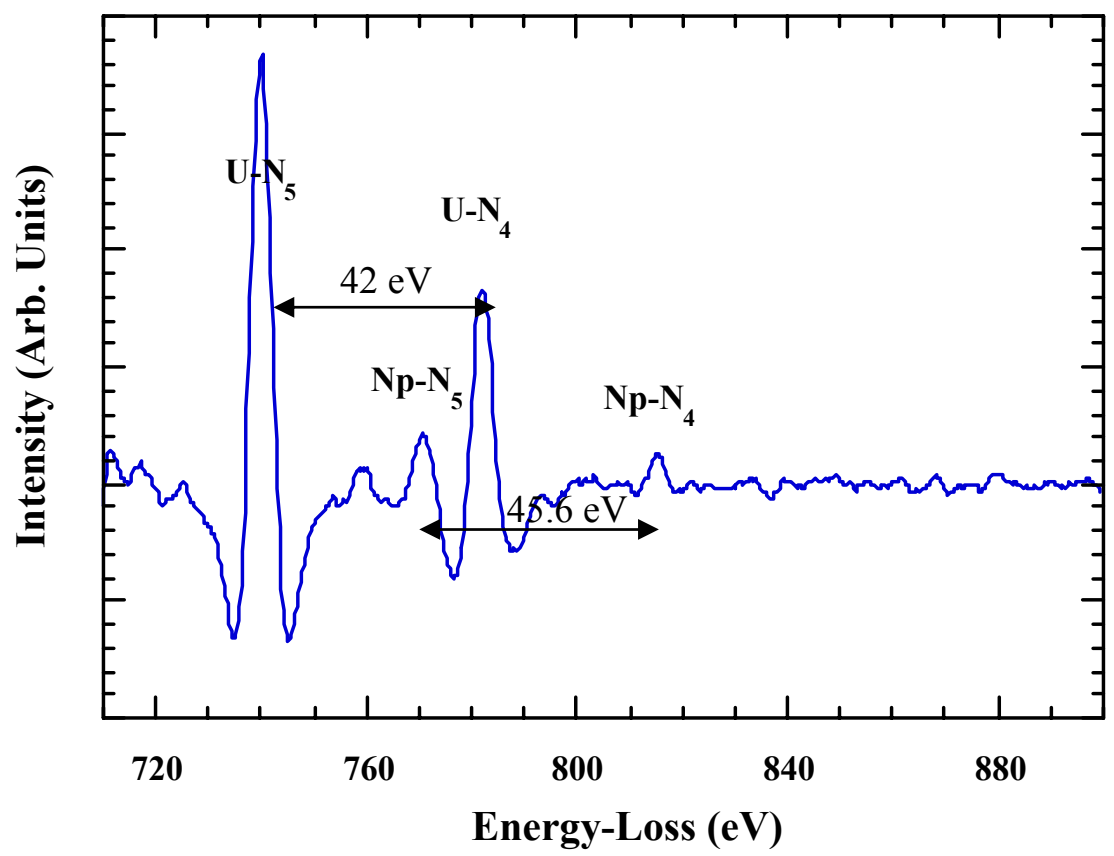

Figure 4.2. EELS evidence of $\mathrm{Np}$ in a Synthetic $\mathrm{U}$ phase (studtite)

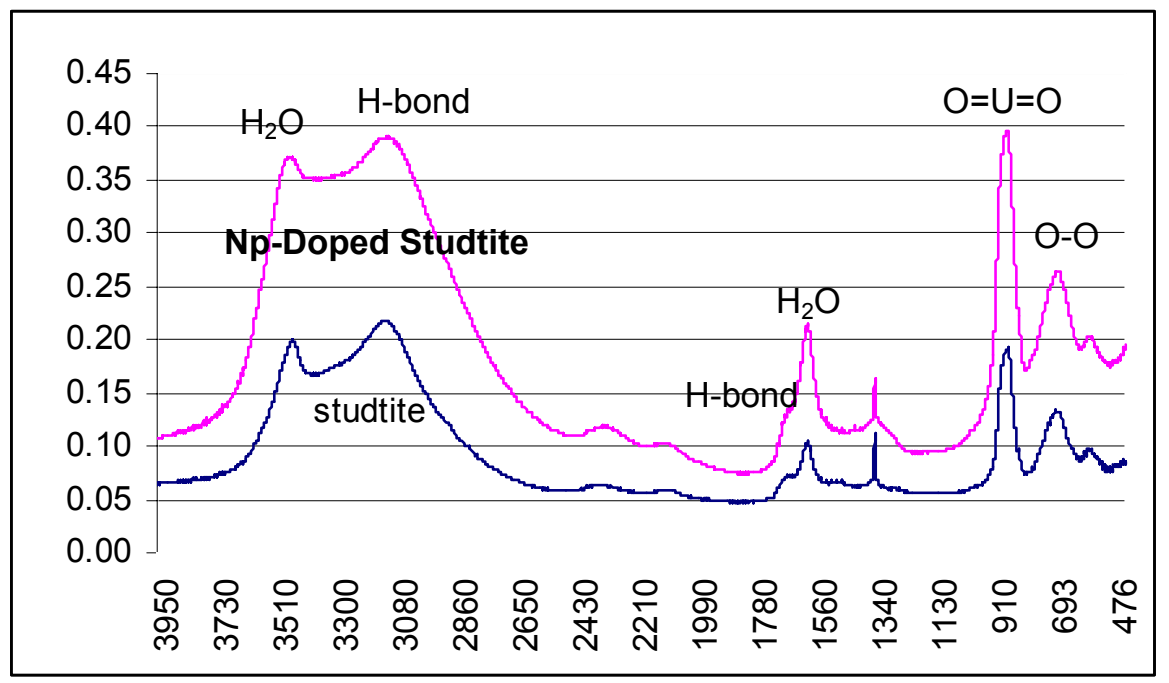

Figure 4.3. Infrared Spectrum of Studtite and Np-Studtite (KBr Pellet) 


\subsection{Analysis of $\mathrm{Np}$ Incorporation into Uranophane}

A series of Np-bearing U(VI) phases were prepared at PNNL (Douglas et al. 2003). In the first set examined, a number of uranophane synthetic mineral phases were analyzed. Optical microscopy of the samples revealed clear differences between the U-only and Np-doped samples (see Figure 4.4). Each of the uranophane samples possessed a different color, and in the TEM, there was no obvious evidence of phase separation. The TEM at the EMSL DOE User Facility was used in this study.

The analysis demonstrated the presence of $\mathrm{Np}$ in the uranophane phases. In Figure 4.5, screen-shots from the Gatan EELS software program show that the distances between the $\mathrm{Np}-\mathrm{M}_{5}$ and $\mathrm{Np}-\mathrm{M}_{4}$ edges are clearly $184 \mathrm{eV}$. Because a smaller energy dispersion was chosen, the separation in the energy peaks was much more certain, as the peaks were separated by twice the number of channels. These examples prove the ability of EELS to detect Np in a U-only matrix.

Figure 4.6 shows two different concentrations of $\mathrm{Np}$ in uranophane. The U-spectra overlap perfectly. Two windows, both $176 \mathrm{eV}$ wide, have been superimposed on the plot. The energy difference between the two edges labeled "Np" are clearly separated by more than $176 \mathrm{eV}$. Indeed, the separation is consistent with the $\mathrm{Np}-\mathrm{M}_{5}$ to $\mathrm{Np}-\mathrm{M}_{4}$ splitting. [If plural scattering dominated under these conditions, variation in the intensity of the $\mathrm{Np}-\mathrm{M}_{5}$ feature would not be expected.] The $\mathrm{Np}$ intensity in one case (the red spectra) is similar to that observed from some of the CSNF samples from the vapor hydration tests.

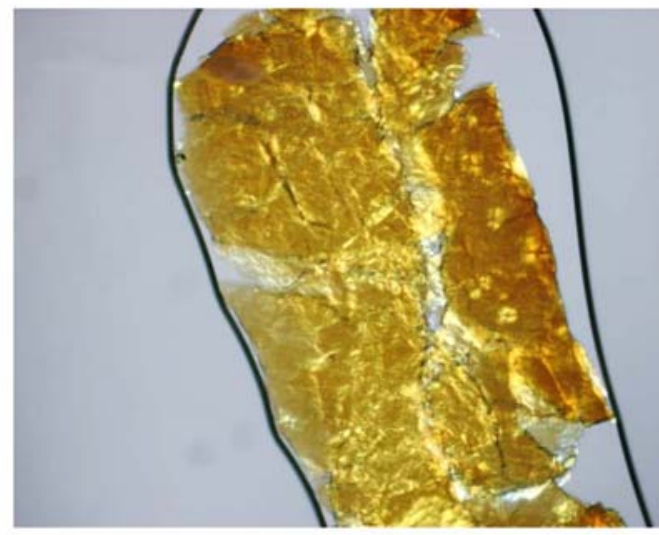

(a)

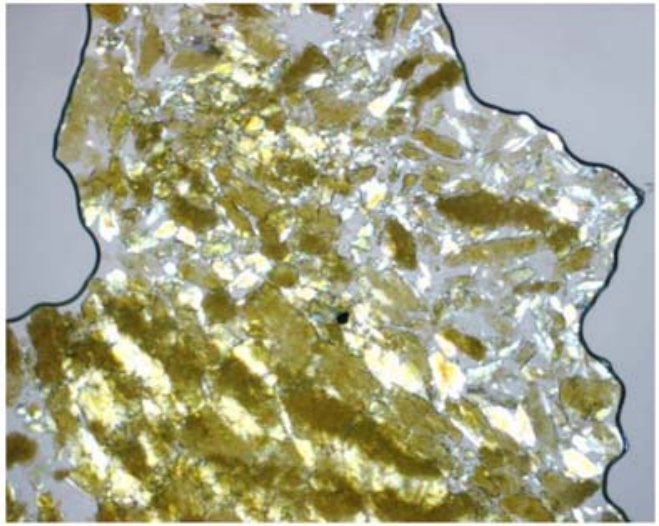

(b)

Figure 4.4. Optical Images of Uranophanes (a) Non-doped and (b) Np-Doped Uranophanes 

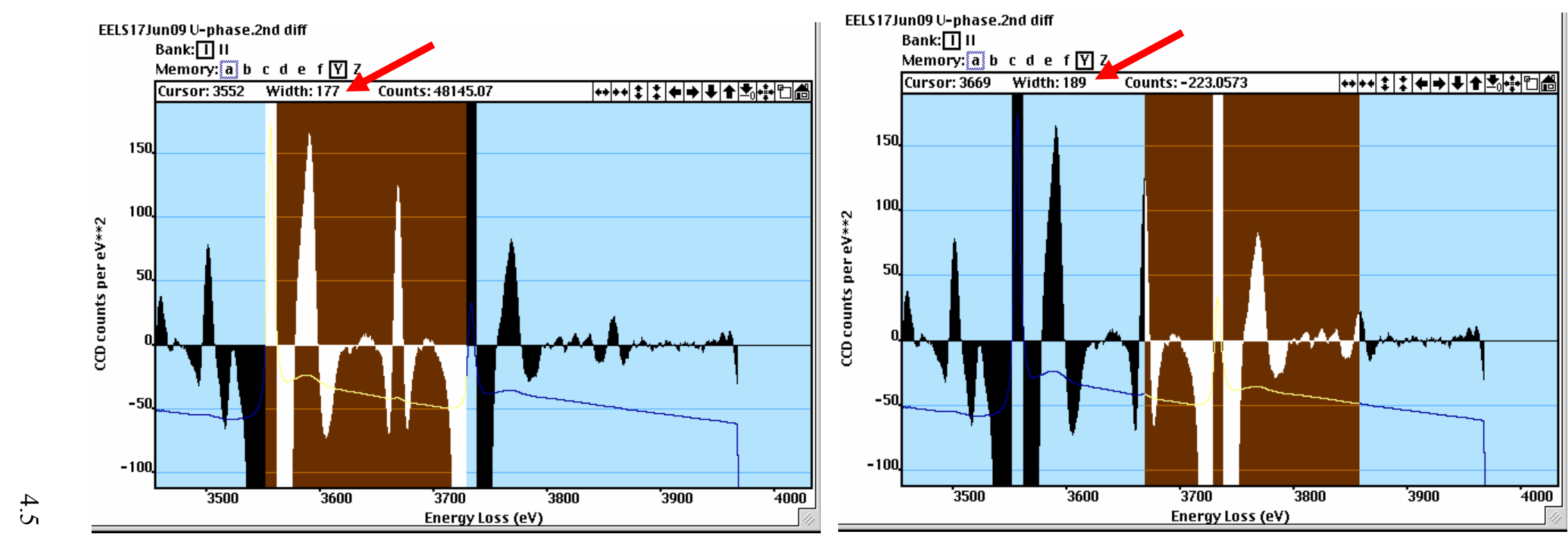

Figure 4.5. Screen Shots from the Gatan Program EL/P Showing the $176-\mathrm{eV}$ Window Between the U M-Edges and the $\sim 189-\mathrm{eV}$ Window Between the Np M-edges. The red arrows point to the energy-width value. 


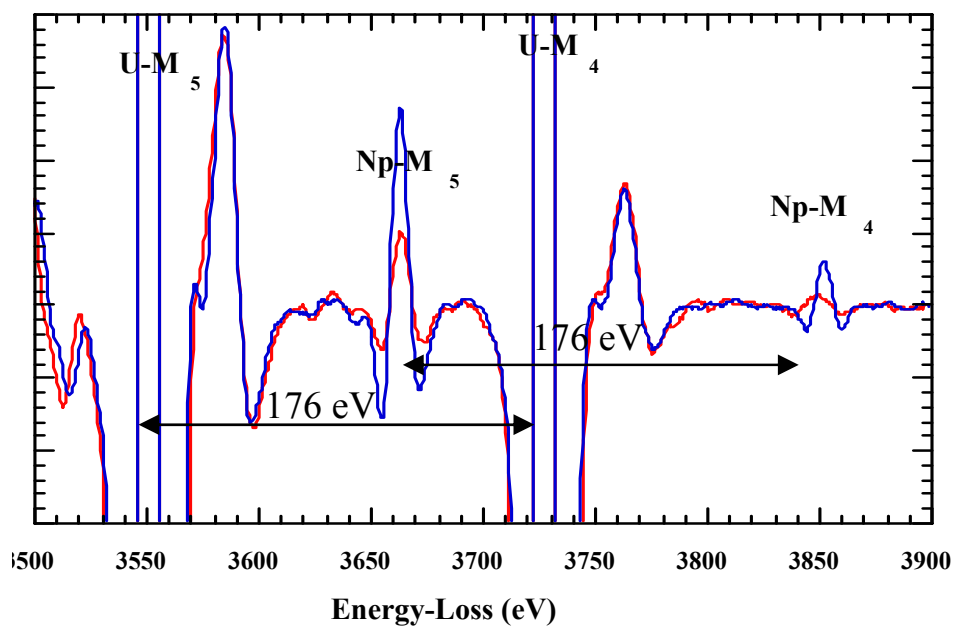

Figure 4.6. Electron Energy-Loss Spectrum of Uranophane Solid Containing Low and high Concentrations of $\mathrm{Np}$.

\subsection{Analysis of Spent Fuel Studtite Phases}

In recent experiments at PNNL, the observed alteration products on spent fuel were different from those observed on $\mathrm{UO}_{2}$ tests. In the spent-fuel tests, studtite was observed to be the major alteration phase. Meta-studtite $\left[\mathrm{UO}_{2}\left(\mathrm{O}_{2}\right)\left(\mathrm{H}_{2} \mathrm{O}\right)_{2}\right]\left(\mathrm{H}_{2} \mathrm{O}\right)$ has been commonly found in the Hanford K-Basin sludges. Additionally, the material has been characterized in high concentration on the cladding of K-East Basin Fuel elements (Abrefah et al. 1998).

The formation of the uranyl (VI) peroxide mineral phase studtite and meta-studtite was observed as the exclusive alteration phases on corroding spent nuclear fuel (see Figure 4.7). These products were formed after immersion in deionized water over a two-year period. A fraction of the samples was additionally observed as an interfacial suspension. Radiochemical analysis of the dried suspensions indicated that ${ }^{237} \mathrm{~Np}$ may be incorporated with the uranyl (VI) peroxide. The structures of the uranyl (VI) peroxy and neptunyl (VI) peroxy species may be similar enough to account for this behavior. $\mathrm{Pu}, \mathrm{Cm}$, and Am were found to be in lower concentration in the uranyl phases; however, 5 to $6 \%$ of the available Pu and Am, based on radionuclide inventory calculations provided by Guenther et al (1986), was co-precipitated with the uranyl phase.

The radiochemical analysis of the filtered liquids and interfacial films from the spent-fuel samples is presented in Table 4.1. The $U$ fraction in the filtered liquid samples was determined by Kinetic Phosphorescence Analysis (KPA). The interfacial films were digested, and the total U was also determined by KPA in triplicate for sample $25-\mathrm{P}_{7}$. In Table 4.2 data are reproduced from hydration tests performed on the same spent fuel in leaching studies performed between 1985 and 1990 at PNNL. For consistency, the radiochemical data are presented in Table 4.2 as $\mu$ g-analyte per g-U for comparison to the inventory calculations for $30.2 \mathrm{MW} / \mathrm{d}$ burn-up fuel at 16 years (Guenther et al. 1986).

The liquids data indicate similar magnitudes of radionuclides at $25^{\circ} \mathrm{C}$. In the $60^{\circ} \mathrm{C}$ sample, the fraction drops off as more $\mathrm{U}$ was dissolved in the five-week period the sample was at temperature. The samples $25-\mathrm{P}_{2}, 25-\mathrm{P}_{7}$, and $60-\mathrm{P}_{5}$ each had different amounts of liquid due to evaporation, but also the solution $\mathrm{pH}$ 
was lower at $60^{\circ} \mathrm{C}$. This observation at $60^{\circ} \mathrm{C}$ also occurred for hydration studies on sintered unirradiated fuel over a two-year period and may be due to the solubility of absorbed $\mathrm{CO}_{2}$.

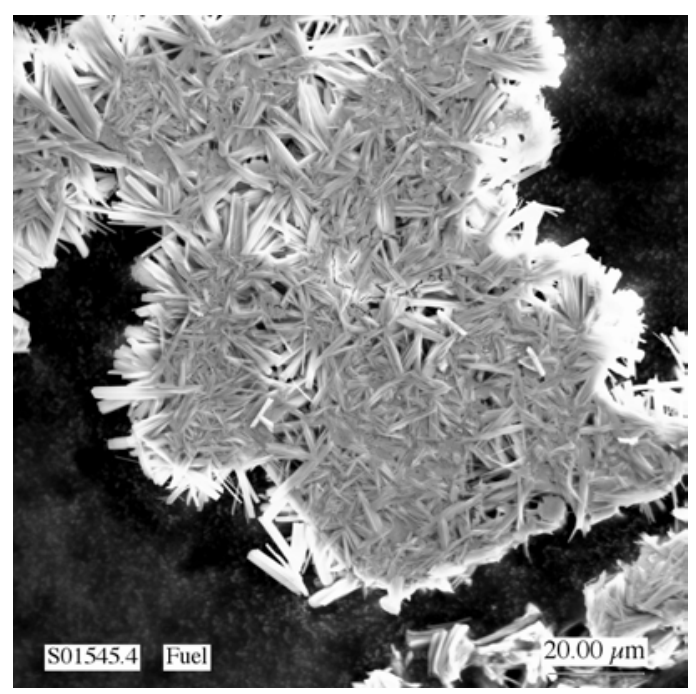

(a)

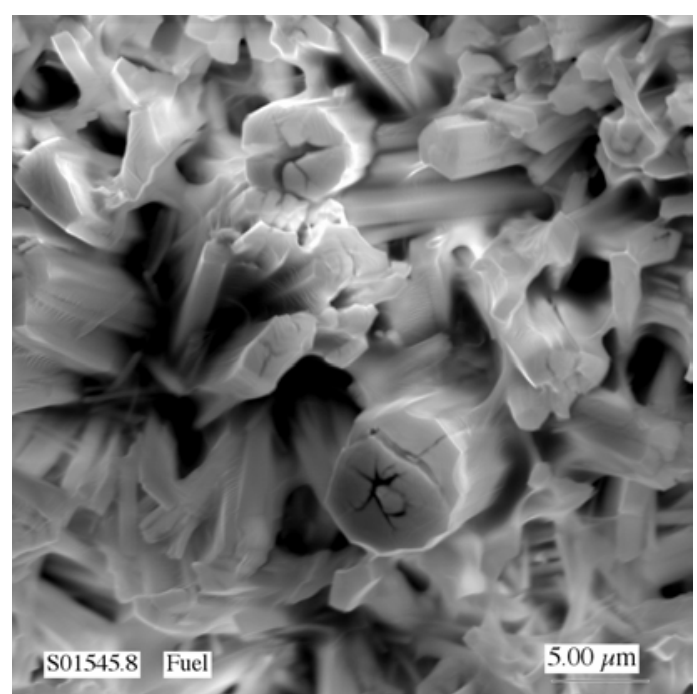

(b)

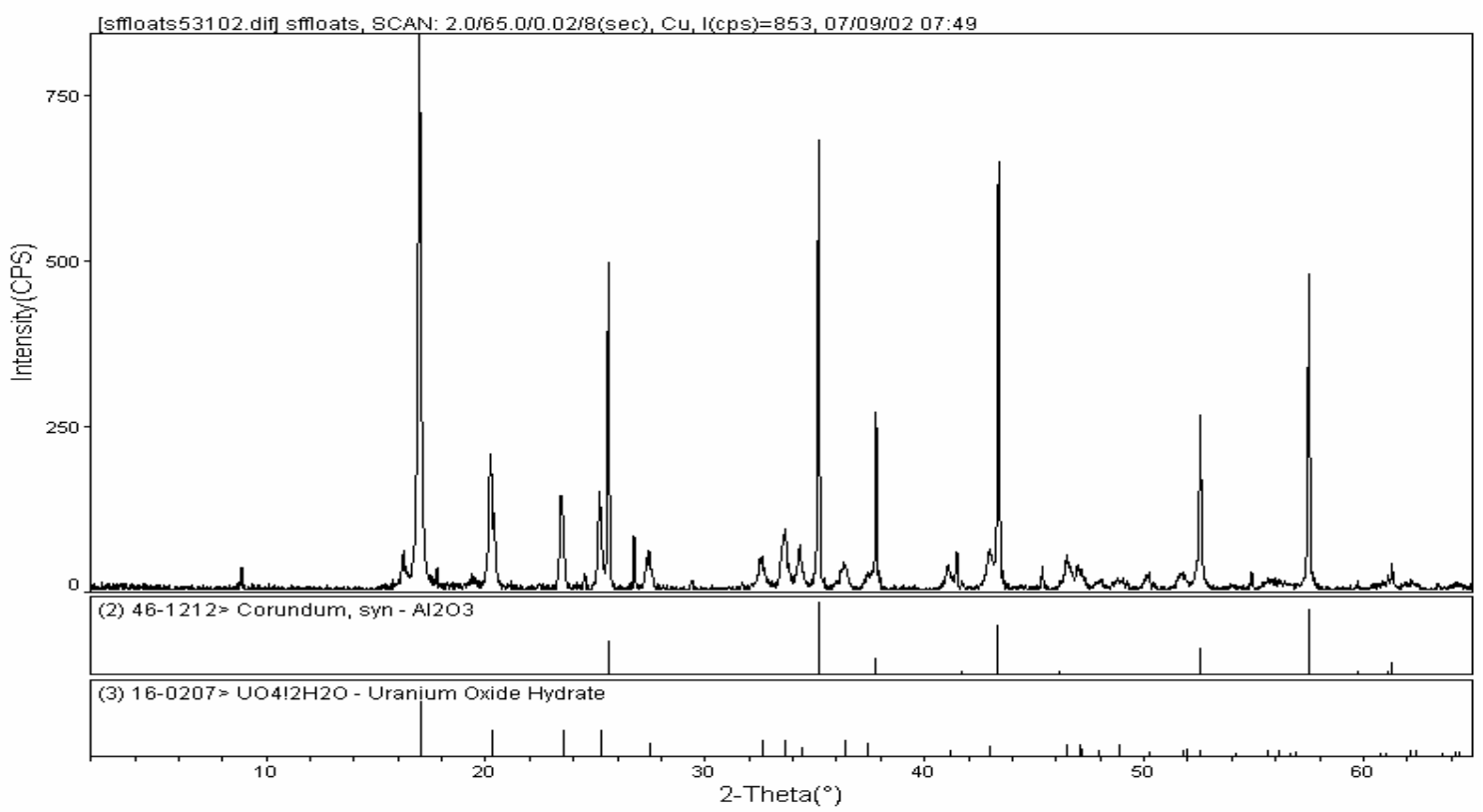

(c)

Figure 4.7. (a) Low Magnification SEM Picture of Meta-Studtite Released from the Surface of Corroded Spent Nuclear Fuel and (b) Higher Magnification Image Showing an Individual Crystallite. The drying in the microscope vacuum chamber may have resulted in the cracking in the particles. (c) X-ray diffraction scan of studtite. 
Table 4.1. Radiochemical Analysis of Dried Films from SNF after 1.5 Years of Immersion

\begin{tabular}{|c|c|c|c|c|c|}
\hline Sample & Total $\mathrm{U}(\mu \mathrm{g})$ & $\begin{array}{l}{ }^{237} \mathrm{~Np} \\
\mu \mathrm{g} / \mathrm{g} \mathrm{U}\end{array}$ & $\begin{array}{c}{ }^{{ }^{239} \mathrm{Pu}} \\
\mu \mathrm{g} / \mathrm{g} \mathrm{U}\end{array}$ & $\begin{array}{l}{ }^{241} \mathrm{Am} \\
\mu \mathrm{g} / \mathrm{g} \mathrm{U}\end{array}$ & $\begin{array}{c}{ }^{243+244} \mathrm{Cm} \\
\mu \mathrm{g} / \mathrm{g} \mathrm{U}\end{array}$ \\
\hline $25 \mathrm{P}_{7}$ & 623 & 330 & 943 & 32.3 & 0.62 \\
\hline $\begin{array}{l}\text { Radionuclide } \\
\text { Inventory } \\
\text { (Guenther et al. } \\
1986 \text { ) }\end{array}$ & & 345 & 12200 & $\bar{~} \overline{516}$ & 15.8 \\
\hline $\begin{array}{l}\text { Percentage } \\
\text { Uptake }\end{array}$ & & $96 \%$ & $8 \%$ & $\mathrm{NV}$ & $4 \%$ \\
\hline
\end{tabular}

Table 4.2. Radiochemical Analysis of Leachates from SNF after 1.5 Years of Immersion

\begin{tabular}{|c|c|c|c|c|c||}
\hline Sample & $\mathbf{p H}$ & $\begin{array}{c}\text { Total } \mathbf{~} \\
(\boldsymbol{\mu g} / \mathbf{m L})\end{array}$ & $\begin{array}{c}{ }^{\mathbf{2 3 7}} \mathbf{N p} \\
\boldsymbol{\mu C i} / \mathbf{m L}\end{array}$ & $\begin{array}{c}{ }^{\mathbf{2 3 9}} \mathbf{P u} \\
\mathbf{C} \mathbf{i} \mathbf{m L}\end{array}$ & $\begin{array}{c}{ }^{\mathbf{1 4 1}} \mathbf{A m} \\
\boldsymbol{\mu C i} / \mathbf{m L}\end{array}$ \\
\hline $25 \mathrm{P}_{2}$ & 6.2 & $6.9 \mathrm{E}-01$ & $6.1 \mathrm{E}-05$ & $1.7 \mathrm{E}-04$ & $4.2 \mathrm{E}-03$ \\
\hline $25 \mathrm{P}_{7}$ & 6.3 & $1.5 \mathrm{E}+00$ & $6.9 \mathrm{E}-05$ & $2.7 \mathrm{E}-04$ & $9.3 \mathrm{E}-03$ \\
\hline Wilson & 8.4 & 0.2 & $2.0 \mathrm{E}-07$ & $3.0 \mathrm{E}-05$ & $1.0 \mathrm{E}-04$ \\
\hline
\end{tabular}




\subsection{Discussion}

This study demonstrates that EELS is capable of detecting low levels of $\mathrm{Np}$ in a uranium matrix provided an energy dispersion is used that allows sufficient channels between features. There is clear evidence for $\mathrm{Np}$ incorporation into U(VI) phases from laboratory-synthesis experiments; however, further work needs to be done on the CSNF experiments under various conditions to justify the case for Np co-precipitation with uranium (VI) phases. Burns ${ }^{(a)}$ has pointed out the importance of counter ions such as $\mathrm{Na}$ to substitute into the interlayer to provide for a charge-balance mechanism. Uranium-bearing phases reported from the spent fuel vapor drip tests tended to contain Ca and Cs (Buck et al. 1998) which may account for these phases containing $\mathrm{Np}$. In spent fuel, stable Cs could also act as a charge compensating ion, as well as any ions from other waste-package materials, including $\mathrm{Na}^{+}$and $\mathrm{K}^{+}$. Experiments looking at Np incorporation by Finch et al (2002) did not include counter ions which may account for the lack of Np incorporation observed.

New advancements in EELS instrumentation should provide improved detection capabilities. For instance, the Gatan TRIDIEM, has more energy channels (2048 Ch) and greater dynamic range (0-60 000 counts) than the GIF2000 (1024 Ch and 0-16 000 counts/Ch) instruments. This would allow one to observe the $\mathrm{U}$ and $\mathrm{Np}$ M-edges at an energy dispersion of $0.3 \mathrm{eV}$. Although the $\mathrm{N}_{4,5}$ edges are very weak, they can be used for analysis in solids that do not contain other elements and will be devoid of interferences, as long as the EELS energy resolution $<1.5 \mathrm{eV}$. The $\mathrm{N}$-edges could not be used during the analyses of spent fuel corrosion products, as other trace elements, including barium, interfered with the analysis.

\subsection{Effect of Oxidation Potential on Np behavior}

Burns et al. (2002) have demonstrated incorporation of $\mathrm{Np}(\mathrm{V})$ into uranophane and $\mathrm{Na}$ compreignacite structures in concentrations equivalent to what was present in solution. Furthermore, Burns ${ }^{\text {(a) }}$ suggest that counter-ions will increase the $\mathrm{Np}$ incorporation into these phases as well. Experiments reported in this study clearly indicate the formation of studtite-related phases with significant uptake of $\mathrm{Np}$. The studtite was present in these fuel tests after two years. Studtite also appears to be a stable phase in these tests. The oxidation state of the $\mathrm{Np}$ in studtite may be (VI) which may make Np incorporation easier; however, the studtite structure consists of chains of uranyl ions rather than the layered motifs typical of schoepite and uranophane phases. This chain-type structure may be more accommodating of the slight structural differences between uranyl and neptunyl groups.

\subsection{Retention of Np during Borosilicate Glass Dissolution}

Although the total amount of $\mathrm{Np}$ in borosilicate glass is low, glass tests are useful because the total amount of reaction can be quantified by measuring boron release. Instead of reporting Np concentrations, actinide studies on glasses have tended to report a retention factor. This is a more useful value when the total amount of the released element in question does not approach a solubility limit. Retention factors are useful for observing co-precipitation behavior. The ratio of $\mathrm{Np}$ to $\mathrm{U}$ in borosilicate-glass formulations is similar to the ratio in the spent fuel. During glass reaction, released U will precipitate as weeksite or sometimes uranophane. Several groups have analyzed Np-doped glasses.

(a) Manuscript in preparation (2003). 
Data from high level waste borosilicate glass tests have tended to show congruent release of $\mathrm{Np}$ and $\mathrm{U}$ with boron (Ebert 1995; Bates and Buck, 1994). It is generally assumed that $\mathrm{Np}$ in borosilicate glass is present in the (V) oxidation state; hence, no oxidation step is required for removal of $\mathrm{Np}$ from the surface. As the reaction proceeds, $U$ concentrations can result in precipitation of $U$ as weeksite. In the glass drip tests that show similar release of $\mathrm{Np}$, secondary $\mathrm{U}$ phases have not been observed.

In Figure 5.1, data extracted from Ebert (1995) demonstrates the co-behavior of $\mathrm{Np}$ and U. This result does not support $\mathrm{Np}$ incorporation.

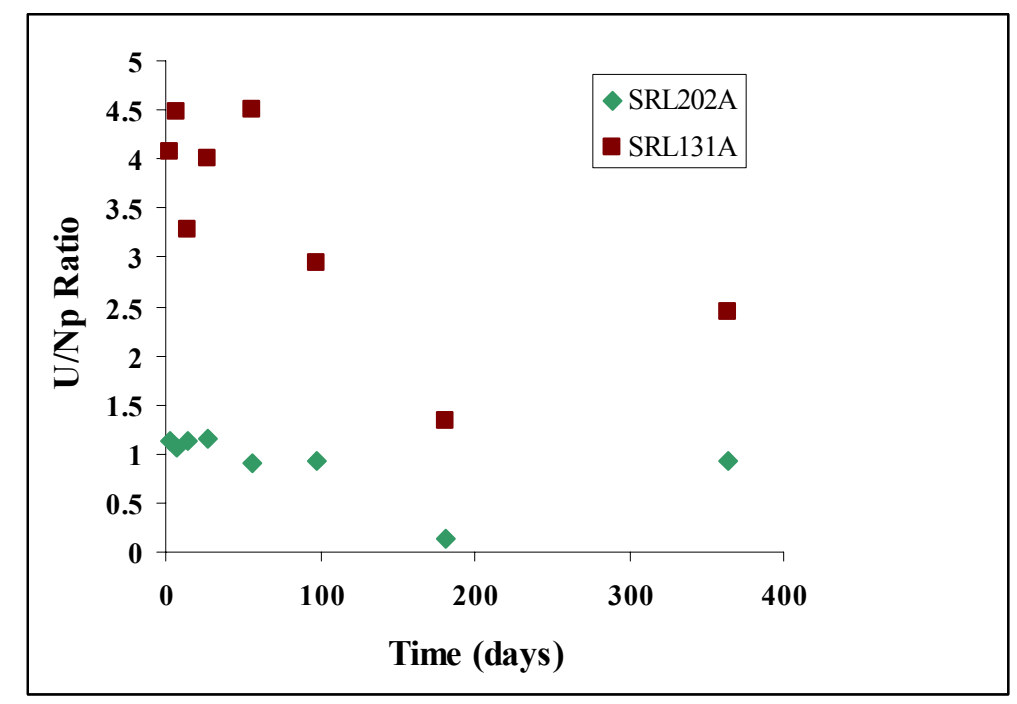

Figure 5.1. Normalized Mass Losses of U/Np for SRL131A and SRL202A Glasses Reacted at 20,000 ${ }^{-1}$ (extracted from Ebert [1995]) 


\subsection{Conclusions}

By looking at the energy gap between the Np M-edge "white-lines," an estimate of Np incorporation may be obtained. However, the energy difference is small, on the order of 7 to $8 \mathrm{eV}$. Poor energy resolution in the spectrum may easily mask the effect. By using smaller energy dispersions (e.g., $\leq 0.5 \mathrm{eV} / \mathrm{Ch}$ ), the plural peak and the Np peak will be separated by more channels and can be more easily identified. The analysis of Np-doped uranophane samples demonstrates the advantage of using a lower energy dispersion. The plural peaks that occur in U samples have been observed in many spectra, in some cases preventing confirmation of the presence of $\mathrm{Np}$; however, analyses of corrosion products using the energyseparation method has provided evidence of $\mathrm{Np}$ in some cases.

The results of the laboratory experiments with studtite and Np-doped studtite indicate that this phase can incorporate a significant amount of Np. This result was confirmed with XRD, IR, and TEM-EELS. The results from the preliminary studies with spent fuel also suggest significant uptake of Np. However, these results need to be duplicated over a larger range of relevant conditions. Synthesized uranophanes show clear evidence for the incorporation of $\mathrm{Np}$.

The evidence of $\mathrm{Np}$ incorporation into uranyl (VI) phases is not well established in CSNF tests, but there is strong evidence for similar chemical behavior for $\mathrm{U}$ and $\mathrm{Np}$ in a number of experiments. The difficulties of testing spent fuel and detecting $\mathrm{Np}$ will continue to cause problems in this area, and it is unlikely that continued testing with spent fuel will resolve this issue. In the light of new studies by Burns et al. ${ }^{\text {(a) }}$ and Douglas et al. (2003) that demonstrate ready uptake of Np into uranophane, the role of secondary $\mathrm{U}(\mathrm{VI})$ phases in attenuating $\mathrm{Np}$, either through sorption or incorporation, may be significant in a repository environment.

Electron energy-loss spectroscopy can be a suitable technique for determining the presence of low levels of $\mathrm{Np}$ in U-bearing solids in spite of artifact problems. No other technique has sufficient spatial resolution combined with sensitivity. Improvements in instrumentation, such as the Gatan TRIDIEM will further improve the ability to detect these low level transuranics.

\subsection{Recommendations}

- Examination of CSNF and related samples should be attempted with a low energy dispersion on the EELS instrument. This report has demonstrated that the detection of $\mathrm{Np}$ with the M-edges can be accomplished at $0.5 \mathrm{eV} / \mathrm{Ch}$ energy dispersion; however, on instruments with more energy channels, such as the Gatan TRIDIEM, even lower energy dispersions would further improve low level detection.

- EELS analysis with the $\mathrm{N}_{4,5}$ edges is probably only effective with $\mathrm{Np}$-only doped solids, although this region is not subject to the type of plural scattering experienced by the M-edges. This is because these are edges are very weak and there can be overlap with other elements.

- New corrosion tests on Np-doped solids should be repeated with charge-compensating ions included. Tests should be conducted over a range of $\mathrm{pH}$ and Eh. The effects of thin-film radiolysis on $\mathrm{Np}$ incorporation should also be quantified.

(a) Manuscript in preparation (2003). 


\subsection{References}

Abrefah J, SC Marschman, and ED Jensen. 1998. Examination of the Surface Coatings Removed from KEast Fuel Elements. PNNL-11806, Pacific Northwest National Laboratory, Richland, WA.

Bates JK, and EC Buck. 1994. "Results of drip tests on sludge-based and actinide-doped glasses." In: International High Level Radioactive Waste Management Conference, Las Vegas, NV, May 22-26.

Buck EC. 1999. "Second difference electron energy-loss spectroscopy with the Gatan Image Filter." Microsc. Microanal. 5:808-809.

Buck EC, RJ Finch, PA Finn, and JK Bates. 1998. "Retention of neptunium in uranyl alteration phases formed during spent fuel corrosion.” Mater. Res. Soc. Symp. Proc. 506:87-94.

Buck EC, DJ Wronkiewicz, PA Finn, and JK Bates. 1997. "A new uranyl oxide hydrate phase derived from spent fuel alteration." J. Nucl. Mater. 249:70-76.

Buck EC, and JA Fortner. 1997. "Detecting low levels of transuranics with electron energy loss spectroscopy." Ultramicroscopy 67:69-75.

Burns PC, ML Miller, and RC Ewing. 1997. "Incorporation mechanisms of actinide elements into the structures of $\mathrm{U}^{6+}$ phases formed during the oxidation of spent nuclear fuel." J. Nucl. Mater. 245:1-9.

Burns PC, and KA Hughes 2002. "Studtite, $\left[\left(\mathrm{UO}_{2}\right)\left(\mathrm{O}_{2}\right)\left(\mathrm{H}_{2} \mathrm{O}\right)_{2}\right]\left(\mathrm{H}_{2} \mathrm{O}\right)_{2}$ : The first structure of a peroxide mineral." Amer. Miner. 88:1165-1169.

Ebert WL. 1995. The Effects of the Glass Surface Area/Solution Volume Ratio on Glass Corrosion: A Critical Review. ANL-94/34, Argonne National Laboratory, Argonne, IL.

Douglas, M, SB Clark, S Utsunomiya, RC Ewing, EC Buck, and BD Hanson. 2003.

"Neptunium association with uranium (VI) silicate solid phases." In: Migration'03, Gyeongju

(Kyongju), Korea, September 21-26, 2003.

Finch RJ, and RC Ewing. 1992. "The corrosion of uraninite under oxidizing conditions." J. Nucl. Mater. 190: 133-156.

Finch RJ, JA Fortner, EC Buck, SF Wolf. 2002. "Neptunium incorporation into uranium (VI) compounds formed during aqueous corrosion of neptunium-bearing uranium oxides." Mater. Res. Soc. Symp. Proc. 713: 647-654.

Finn PA, EC Buck, M Gong, JC Hoh, JW Emery, LD Hafenrichter, JK Bates. 1994. "Colloidal products and actinide species in leachate from spent nuclear fuel." Radiochem. Acta. 66/67:189-187.

Guenther RJ, DE Blahnik, TK Campbell, UP Jenquin, JE Mendel, LE Thomas, and CK Thornhill. 1986. Characterization of Spent Fuel Approved Testing Material ATM-103. PNL-5109-103, Pacific Northwest National Laboratory, Richland, WA. 


\section{Distribution}

No. of

Copies

OFFSITE

4 Bechtel SAIC Company, LLC 1180 Town Center Drive Las Vegas, NV 89144

Attn: Yueting Chen (2) FJ Pearson Howard Atkins Christine Stockman

1 Argonne National Laboratory 9700 South Cass Avenue Argonne, IL 60439

Attn: Dr. James C Cunnane (2)

1 Sandia National Laboratory 1515 Eubank SE

Albuquerque, NM 87123

Attn: Dr. Patrick V Brady

2 Australian Nuclear Science and Technology Organisation New Illawarra Road, Lucas Heights, NSW 2234

Attn: Michael Colella

Dr. Katherine L Smith
No. of

Copies

\section{ONSITE}

37 Pacific Northwest National Laboratory Edgar C Buck (6)

P7-27

Brady D Hanson (20)

P7-27

Bruce K McNamara

$\mathrm{P} 7-25$

Judah I Friese

$\mathrm{P} 7-22$

Chong-Min Wang

K8-93

Jonathan P Icenhower

K6-81

Alice Dohnalkova

P7-50

Larry E Thomas

P8-16

Kenneth M Krupka

K6-81

John M Zachara

P8-96

Andrew R Felmy

P8-96

Technical Report Files (2)

Distr. 1 